\title{
Los desastres de la guerra: reflexiones sobre la muerte de prisioneros y cautivos durante la Edad Media*
}

\author{
War disasters: reflections on the death of prisoners \\ and captives during the Middle Ages
}

José Manuel Calderón Ortega**

\begin{abstract}
RESUMEN ABSTRACT
A lo largo de la Historia paulatinamente fue imponiéndose el respeto de la vida de los prisioneros por motivos religiosos, estratégicos o, casi siempre, económicos al venderlos como esclavos o cobrar rescates por su libertad. Esta tendencia, sin embargo, en ocasiones no fue respetada y los prisioneros perdieron la vida, fríamente ejecutados por sus captores. El autor reflexiona acerca de los motivos que indujeron a reyes y jefes militares a este proceder.

\section{PALABRAS CLAVE}

prisioneros de guerra, cautivos, rescates, muerte de prisioneros, guerras civiles, rebeldes, traidores, fanatismo, venganzas, represalias, profanación de cadáveres.

The respect for the lives of prisoners was imposed progressively throughout history by religion reasons, strategic and most of the time economic motives, as prisoners were sold as slaves and ransoms were paid to obtain their freedom. However, this tendency wasn't always followed given that prisoners lost their lives as they were, coldly executed by their captors. The author reflects about the motives that lead kings and military chiefs to behave in a way.

\section{KEY WORDS}

war prisoners, captives, ransoms, death of prisoners, civil wars, rebels, traitors, fanaticism, revenges, reprisals, corpse desecrations.
\end{abstract}

* Fecha de recepción del artículo: 2009-09-15. Fecha de aceptación del artículo: 2009-11-30.

Este trabajo forma parte del Proyecto de Investigación del Área de Historia del Derecho «Cautivos y prisioneros en el Derecho histórico español». Universidad de Alcalá de Henares.

** Universidad de Alcalá de Henares. C.e.: jmanuel.calderon@uah.es 


\section{INTRODUCCIÓN}

La práctica habitual desde épocas muy antiguas fue la muerte de los prisioneros de guerra o su reducción a la condición de esclavos y, en este sentido, conviene recordar que algunas de las primeras manifestaciones artísticas, como las famosas paletas predinásticas egipcias, representan a los faraones Narmer o Aha ejecutando de forma ritual a los jefes de los ejércitos derrotados y también a prisioneros, sólidamente atados y esperando un destino sombrío que en ocasiones, como en la época de esplendor del imperio asirio, podía resultar verdaderamente espeluznante, ya que siempre atribuyeron al uso del terror una enorme importancia como arma de indudable valor estratégico.

Estas obras de arte y otras posteriores estaban dedicadas a ilustrar las conmemoraciones de campañas victoriosas, que significaban la destrucción más o menos completa de pueblos y culturas y la ejecución de los prisioneros o su venta en los mercados de esclavos que surgieron en distintas partes del Mediterráneo, constituyendo desde fechas muy tempranas uno de los mejores negocios para los comerciantes de todo el mundo conocido ${ }^{1}$. El uso institucionalizado de la violencia contra los vencidos fue practicado también por el pueblo de Israel durante su conquista de Tierra Santa, aunque pretendieran justificarlo con un componente religioso, que aceptaba la destrucción de personas y bienes como una exigencia de su Dios².

Existen demasiados testimonios a lo largo de la Historia de ejecuciones de prisioneros que informan de su uso con motivaciones interesadas y, pese a que en fechas relativamente tempranas comenzara a abrirse paso la posibilidad de obtener

\footnotetext{
1 La existencia de esclavos procedentes de la actividad guerrera está atestiguada desde fechas muy tempranas en todos los grandes imperios de la Antigüedad, siendo destinados a todo tipo de actividades, desde la guerra, integrados en unidades especiales que, paradójicamente, velaban por la seguridad de quien los había reducido a su condición, hasta para la realización de los trabajos más duros de la construcción de templos, palacios ó fortificaciones y en el labores agrícolas.

2 FERNÁNDEZ UBIÑA, José, Cristianos y militares. La iglesia antigua ante el ejército y la guerra, Granada, 2001, p. 118, a quien seguimos en este punto, escribe. «En el imaginario religioso que daba a la guerra un carácter cultual y convertía en tabú sus despojos, debe entenderse la teología del herem, que Israel compartió con otras culturas del entorno, por la cual se consagraba al dios la totalidad o parte del botín y de los bienes expoliados al enemigo, incluyendo los prisioneros. En el Pentateuco hay numerosos ejemplos de estas prácticas; así en Números 31 Yahvé pide a Moisés la aniquilación total de bienes y personas madianitas. Fineas llevó adelante la misión, pero hizo cautivos a mujeres y niños y se apoderó de algún botín. Moisés indignado le ordenó matar a los cautivos indefensos salvo a las vírgenes. También en libro de Josué, 6,17,20-21».

«Sin embargo es cierto que la teología del exterminio no siempre se formuló en la Biblia de manera tan absoluta, ni siquiera en la guerra por la Tierra Santa, pues lo más frecuente era declarar tabú, es decir, consagrado a Yahvé solo una parte del botín y de los prisioneros, usualmente las minorías dirigentes o los adultos en general (todos los que orinan contra la pared)... En este clima de encarnizamiento cabe pensar que surgiría inicialmente la teología destructiva del herem con su ilusión primitiva de interesar al dios en la victoria consagrándole todo lo adquirido en ella, es decir, los enemigos y el botín. El carácter obviamente antieconómico de esta práctica debió propiciar su temprana evolución, restringiéndose el anatema, al menos desde la Monarquía, a determinados bienes que se consagraban a Yahvé y que, por cierto, constituyeron las primeras riquezas del tesoro del templo».
} 
un rendimiento económico, los gobernantes siempre se reservaron la posibilidad de utilizar su muerte como medio de afianzar su poder.

No cabe duda de que la llegada del Cristianismo significó un cambio revolucionario en lo que había sido entonces la consideración de los prisioneros de guerra y cabe atribuir a San Agustín el mérito de ser el primero en reflexionar sobre la guerra justa en el seno del Cristianismo y sobre la actitud a adoptar frente a un enemigo ${ }^{3}$. El obispo de Hipona había sido influenciado por los escritos de Cicerón, sobre todo por su tratado De officis ${ }^{4}$ y entre su correspondencia se encuentra una carta dirigida al papa Bonifacio (418-422), en la que habla de la guerra y del oficio de las armas. Siguiendo a Cicerón, establecía algunos de los preceptos que los cristianos hicieron suyos, como evitar los excesos en la guerra, sobre todo la venganza y las represalias, respetar la palabra dada y el derecho del vencido a la misericordia del vencedor ${ }^{5}$. La influencia de San Agustín fue fundamental durante toda la Edad Media y los grandes canonistas y teólogos, desde Isidoro de Sevilla hasta Tomás de Aquino, citaron continuamente los principios agustinianos al tratar sobre los sujetos de las actividades militares.

No obstante, lo que para el pueblo cristiano debía ser una norma absoluta, no asesinar ni maltratar a ninguno fuera de la batalla y mostrar respeto a la persona del prisionero de guerra, se encontraba en abierta contradicción con la práctica militar ya que, durante mucho tiempo, existió la costumbre de ejecutar a los jefes y en especial a los reyes enemigos capturados en combate. Esta forma de actuar revestía una evidente lógica, al constituir la forma más rotunda de refrendar una victoria aplastante y evitar posteriores revanchas de los vencidos ${ }^{6}$.

3 Agustín escribió si la rebelión y la resistencia han acabado, el vencido o el prisionero tienen derecho a la compasión, sobre todo cuando la clemencia no compromete los intereses de la paz (Epístola 189, VISMARA, Giulio, «Problemi storici e istituti della guerra altomedievale», en, Settimane di Studio del Centro Italiano di Studi sull'Alto Medioevo, XV, Ordinamenti militari in Occidente nell'Alto Medioevo, Spoleto, 1968, v. II, pp. 1127-1200 [1188]. Frente a la tradición que entregaba al vencido en las manos del vencedor y no hacía que la vida le fuera conservada, convirtiéndolo en esclavo, el obispo de Hipona defendía que la humanidad del prisionero debía ser respetada, ya que como hombre tiene derecho a que el vencedor comprenda y participe de su sufrimiento. ORTEGA, Juan Fernando «La Paz y la guerra en el pensamiento agustiniano», Revista española de Derecho Canónico, XX, 1965, pp. 5-35. En las páginas 32 y 33, menciona los capítulos segundo y sexto de De Civitate Dei, en que habla del distinto comportamiento de paganos y cristianos en relación a los vencidos, considerando que el Cristianismo ha introducido una nueva forma de interpretar el lus belli, con el respeto a los lugares sagrados o la inviolabilidad de doncellas y, en la medida de lo posible, de la muerte, de la esclavitud y del pillaje.

4 Escribía Cicerón que, conseguida la victoria, había que respetar las vidas de los enemigos que no fueron crueles ni salvajes, pero al parecer entre éstos no estaban ni Cartago ni Numancia ni Corinto, cuya aniquilación aprueba con gran comprensión patriótica, pues era el mejor medio para asegurar la paz. De officis, I,II,35, FERNÁNDEZ UBIÑA, Op. cit. [n. 2] p. 96.

5 Afirma que la fe prometida debe ser guardada también al enemigo contra el que se está en guerra. En esta misma carta, Agustín dice también que debe ser por necesidad y no por voluntad que se de la muerte al enemigo al que combatimos. Si la resistencia o la rebelión llaman a la violencia, el vencido o el cautivo tienen derecho a la misericordia, sobre todo cuando el mantenimiento de la paz está asegurado... -GRAVELLE, Yves, Le problème des prissoniers de guerra pendant les croisades orientales, 1095-1192. University de Sherbrooke, MA. Thesis, 1999, p. 27.

6 Los ejemplos son muy numerosos, pero por citar algunos. Año 493. Teodorico vence a Odoacro, lo apresa y ejecuta. ALFONSO EL SABIO, Primera Crónica general de España, ed. MENÉNDEZ PIDAL, 
Siempre constituyó una excusa muy utilizada la muerte o reducción a la servidumbre de los enemigos que profesaban religiones distintas. Los ejércitos bizantinos de Justiniano encontraron una buena justificación para sus atrocidades sobre vándalos y ostrogodos en su credo arriano, también los francos en sus luchas contra los visigodos o, en general, los cristianos y musulmanes en sus interminables guerras. Al mismo tiempo, la antigua costumbre de matar prisioneros con carácter ejemplarizante continuó presente en la mentalidad guerrera, ya que se consideraba que los beneficios eran mayores que los escrúpulos de conciencia, como ocurrió durante la conquista musulmana de España ${ }^{7}$.

Las distintas religiones muchas veces aprobaron la muerte de los prisioneros $y$, en este sentido, resultan sobradamente conocidas las campañas de exterminio de Carlomagno contra los sajones entre 772 y 804 , que sin embargo encontraron justificación en la obra de su cronista Eginardo ${ }^{8}$, o la famosa Bula de Nicolás I dirigida a los búlgaros, en la que les reprochaba su ferocidad hacia los enemigos vencidos, aunque considerara una atenuante su reciente conversión al Cristianismo9.

Esta práctica estaba más cercana a la Táctica de León VI el Sabio, emperador de Bizancio de principios del siglo X, que a los principios del Cristianismo. Resulta evidente que la orden para sus comandantes no se inspira en el principio cristiano sino sobre todo en el criterio de oportunidad en la conducta de la guerra, no el respeto del hombre en el enemigo sino la simple consideración de la eventual necesidad o utilidad a los fines bélicos ${ }^{10}$. Esta forma de actuar alcanzaría una de las

Ramón, Madrid, 1906, C. 429, aunque al parecer, lo que debió ocurrir es que Teodorico ordenara su asesinato poco después de firmada la paz entre ambos. SUÁREZ FERNÁNDEZ, Luis, Manual de Historia Universal, t. III, Madrid, 1972, p. 27. Año 610. Heraclio derrota a Focas y ordena su ejecución, Crónica Mozárabe de 754, ed. LÓPEZ PEREIRA, José Eduardo, Zaragoza, 1980, p. 25.

7 Así, año 712 o 713. Conquista de Zaragoza por los moros, que crucifican a señores y nobles y descuartizan a jóvenes y lactantes. LÓPEZ PEREIRA, Op. cit., p. 73.

Año 732. Carlos Martel combatió las ciudades de Aviñón y Narbona, conquistándolas y matando a todos los moros que encontró en ellas. ALFONSO X EL SABIO, Op.cit. [n. 7], c. 577 y 578.

Hacia 750. Reinado de Alfonso I, toma muchas ciudades y mata a los sarracenos. "Crónica alfonsina (versión ad Sebastianum)», Crónicas de los reinos de Asturias y León, ed. CASARIEGO, Jesús Evaristo, León, 1985, p. 65-79 [70].

8 Eginardo justifica el proceder de Carlomagno en el hecho de que los sajones, como casi todas las naciones que habitaban la Germania, eran de naturaleza feroz y hostiles a la religión, además practicaban el culto del demonio y no juzgaban deshonroso violar o transgredir las leyes divinas o humanas, por cuanto ellos se burlaban de la magnanimidad del monarca y todavía habían protagonizado actos de represión sin piedad, como en la ya recordada masacre de Verden. EGINARDO, Vie de Charlomagne, editée et traduit par Louis Halphen, Paris, 1967.

9 En la Bula Ad consulta Bulgarorum, los acusaba de haber pecado gravemente por matar a sus enemigos después de la victoria, asesinando mujeres y niños. El papa reclamaba a los búlgaros la observancia del principio de humanidad hacia el enemigo que ellos habían violado «vosotros habéis pecado gravemente matando a vuestros enemigos después de la victoria, quitando la vida a sus mujeres y sus hijos inocentes, erais obligados a respetar en la medida de lo posible a respetar a vuestros enemigos en el combate. Sabemos que habéis obrado así por ignorancia más que por malicia, aunque tenéis que hacer penitencia». Nicolás I, Epístola 97. VISMARA, Op. cit. [n. 3], p. 1184, CONTAMINE, Philip, La Guerra en la Edad Media, Madrid, 1984, p. 335.

10 León VI el sabio en su Táctica, 16,11, ordenaba «no matar los prisioneros antes de la conclusión de la guerra, sobre todo si se trata de hombres nobles e ilustres, ya que debe considerarse que el éxito de la guerra es siempre dudoso, ya que puede acaecer que la misma victoria que has conseguido pue- 
más altas cotas de la infamia en la conducta del emperador Basilio II durante sus guerras contra los búlgaros a comienzos del siglo siguiente, cuando ordenó cegar a los quince mil prisioneros que había capturado, siendo conducidos por compañeros mancos a tierras búlgaras ${ }^{11}$.

\section{LA MUERTE DE PRISIONEROS Y CAUTIVOS EN LA ESPAÑA MEDIEVAL ${ }^{12}$}

Mientras esto acaecía en el escenario europeo, la situación en España no constituía una excepción, ya que después de unos primeros años de depredaciones y muertes causadas por la conquista musulmana, posteriormente las crónicas comienzan a mencionar la existencia de cautivos a ambos lados de la frontera y, también, cómo los propios musulmanes fueron conscientes de la utilidad de participar en la dinámica de los rescates ${ }^{13}$.

Sin embargo y pese a que la costumbre se inclinaba cada vez más hacia el respeto de la vida de los prisioneros, no tanto por consideraciones éticas sino más bien por razones de tipo práctico, como la necesidad de mantenerlos con vida para proceder a su rescate, intercambiarlos por otros prisioneros o, incluso, para su utilización en distintas actividades productivas. Por ello, la descripción por cronistas e historiadores de ejecuciones de cientos e, incluso, de miles de estos desgraciados, induce a reflexionar acerca de las motivaciones de reyes y jefes victoriosos para proceder de esta manera y, quizá, debamos concluir que en la mayor parte de las ocasiones no se trató de una violencia ciega e injustificada, sino que obedecía a distintas causas, reduciéndose a episodios protagonizados por personajes que han pasado a la Historia como paradigmas de fanatismo o de crueldad.

da dar la vuelta. Puede ocurrir que alguno de sus soldados caiga en manos del enemigo y pueda hacer un cambio y resarcir el daño obteniendo de tus enemigos el rescate de tus amigos y aliados. Si los enemigos no quisieran adherirse a tu propuesta entonces traerá venganza, tratando a tu arbitrio a los prisioneros». VISMARA, Op. cit. [n. 3], p. 1185.

11 En 1014, después de derrotar a los búlgaros en Quimbalongo. SUÁREZ FERNÁNDEZ, Op. cit. [n. 7], p. 258.

12 Con carácter general y siguiendo la clásica diferenciación establecida desde Partidas, consideraremos al cautivo como el prisionero que profesa una religión distinta a la de su captor, en tanto que la acepción de prisioneros la reservaremos para los enemigos capturados del mismo credo religioso. Al mismo tiempo respetaremos la terminología empleada por otros autores, aunque no coincida exactamente con la propuesta, cuando utilicemos alguna cita contenida en sus obras. Las Siete Partidas de don Alfonso el Sabio, Madrid, 1807, en adelante PARTIDAS, II, XXIX,1

13 Hacia 750. La Crónica de Alfonso I menciona que ganó muchas ciudades, liberando cautivos con los que pobló mucha tierra. ALFONSO EL SABIO, Op. cit. [n. 7], c.581. Finales del siglo VIII. Reinado de Hixem en Córdoba y el cronista dice que era tan piadoso que todo cuanto ganaba lo daba a sus caballeros y en sacar cautivos de tierra de cristianos. ALFONSO EL SABIO, Op. cit. [n. 7], c. 610. En la Reconquista se distinguen claramente dos periodos en el trato a los prisioneros de guerra. Los reyes primitivos adoptaron un sistema de exterminio de los enemigos capturados que fue pronto cediendo a la implantación de una esclavitud análoga a la romana, RAMOS LOSCERTALES, José María, El cautiverio en la Corona de Aragón, siglos XIII, XIV y XV, Zaragoza, 1915, p.122. 
Resulta evidente que los prisioneros de condición nobiliaria tenían muchas más posibilidades de conservar la vida que los simples soldados, en cuyo caso las consideraciones humanitarias o utilitarias apenas significaron un alivio en su triste destino. Además, la costumbre establecía el respeto de la vida del caballero rendido, como bien recuerda Bouvet, que tanta influencia ejercería en los tratadistas españoles del siglo XV, al contraponer la práctica antigua, que aceptaba la muerte del prisionero en cualquier momento, con la imperante en su tiempo, cuando ya estaba perfectamente arraigado el principio del Decreto que establecía que después que un onbre es en la presión, misericordia le es devida, y por lo que incluso contemplaba la exigencia de responsabilidades del matador ante el juez o la justicia superior ${ }^{14}$.

No obstante, el autor admite el mal menor, la ejecución de prisioneros, si con ello se alcanza un beneficio mayor, básicamente terminar con los males de una guerra él le deve aver merçed sino que por su deliverança onbre se rreçelase de aver guerra mayor. Para justificarlo, recordaba la muerte de Conradino, rendido a sus enemigos y aceptado como prisionero, al que después, el rey Carlos de Nápoles ejecutó con el parecer afirmativo de sus consejeros para acabar con la guerra ${ }^{15}$.

Esta justificación de la muerte de prisioneros tuvo también un ejemplo depurado en el ámbito español con la muerte de Pedro I. Refugiado en el castillo de Montiel, hubo de entregarse a sus enemigos con la promesa de salvar la vida. No

14 «Mas sobre el otro punto de la demanda ca segunt derecho escripto, antiguamente un onbre podía matar su presonero a su voluntad, que diremos nos en el tiempo presente, por çierto así creo yo bien que si un cavallero o un canpión toma a otro en la batalla, él lo puede matar frescamente mas si él lo lieva a su posada e después sin otra rrazón lo quería matar, yo pienso que él devría dello rresponder delante de la justiçia o delante / fo 85 del señor, e son aquestas las rrazones por las quales yo digo aquesta opinión, en la batalla matar su enemigo es primisso de derecho e por el señor, mas fuera la vatalla un ome qualquier que sea non puede matar a otro si non defendiéndosse, excepto el señor por juyzio, ca a él pertenesçe fazer morir por justiçia en su tierra e non a otro onbre, segunt derecho escripto, mas aquel que es ya preso e otro mal non faze nin otros por él, es quiera o non en la obediençia del señor pues por qual derecho lo matara, que si lo mata non deva prender justiçia, ca dize un derecho escripto que después que un onbre es en la presión misericordia le es devida, si no que ome dubdasse que si él escapa aun sería mayor la guerra, e en aquél caso yo digo que el conosçimiento debe seer del señor prínçipe que faze la guerra e non paz de un cavallero o de un peón, el qual lo ha apresonado, al qual non pertenesçe en manera alguna la jurisdiçión de aquella tierra». BOUVET, Honoré, Árbol de batallas. Prólogo y traducción de Antón de Zorita, Madrid, Biblioteca Nacional, Mss. 10203. fo 84 v-85.

15 «Pues demando yo agora si por alguna aventura el capitán de la batalla es preso por su enemigo, si segunt buena rrazón e segunt justiçia aquél que lo ha tomado si le debe perdonar... / fo 65 e pues que ansí la ordenança de natura por qual rrazón el onbre que es más rrazonable no fará vengança de aquél que le es contrario e mortal enemigo aun más fuerte segunt la ley çivil aquél que es presso en batalla es siervo o captivo de aquél que lo toma pues porque non fará el su voluntad de lo suyo, mas el decreto es en contrario de aquesta rrazón ca dize que después que un onbre es en la presión misericordia le es devida pues si ella le es devida como pues que derecho lo quiere lo podrá matar aquél que lo ha tomado sin fazerle tuerto, e grant sin rrazzón aun más fuerte ca dize otro decreto ca pues que un onbre ha vençido a otro él es obligado de perdonarle pues es tenudo de perdonarle porque lo deve matar, agora en aquesta questión me paresçe que aquél que en batalla a presonado su enemigo espiçialmente el duque o el mariscal o capitán de la batalla, verdaderamente segunt Dios e segunt theología e derecho de decretos, e así lo prueva el decreto sobredicho e por aquesta rrazón el buen rrey Carles de Napoles fizo por sentençia morir a Corraldino e le fizo cortar la cabeça e todos los del consejo dezían que si él escapava la guerra nunca avría fin nin la paz nunca sería en el rreyalme mientras que aqueste Corraldino viviesse, todavía segunt derecho de las leyes pues que un onbre es preso aquél que lo prende puede fazer dél a su guisa por las sobredichas leyes". BOUVET, Op. cit. fo 64 v-65v. 
obstante, su suerte estaba echada y fue asesinado por su hermanastro Enrique de Trastámara $^{16}$.

Hemos mencionado muertes que tuvieron resonancia internacional, pero a lo largo de la historia medieval hubo numerosas ocasiones en las que los vencedores ejecutaron a personajes importantes de los ejércitos derrotados aplicando una estrategia que no conocía de diferencias de credos, al considerar que ciertos actos de crueldad podían contribuir al final de las hostilidades en lugar de facilitar el pago de rescates y evitar la reanudación de la guerra ${ }^{17}$.

Al mismo tiempo, personajes históricos dieron muestras durante sus guerras de una crueldad que escandalizó a sus contemporáneos, no por ordenar ejecuciones masivas de prisioneros poco importantes, sino fundamentalmente por no respetar convenciones caballerescas que ya se consideraban arraigadas en la mentalidad nobiliaria, como fue el caso de Pedro I de Castilla ${ }^{18}$ o César Borgia ${ }^{19}$.

16 «Por la Europa en lucha pero imbuida de los principios caballerescos se extendió rápidamente la noticia y don Pedro recibió loas que de otra forma no hubiera logrado. Enrique y Du Guesclin sufieron las más duras críticas pero su condición de vencedores les puso a cubierto de las consecuencias de sus actos». DÍAZ MARTíN, Luis Vicente, Pedro l, 1350-1369, Valladolid, 1995, pp. 338-9.

17 Por citar algunos ejemplos, año 873. Muhammad I encabeza una aceifa contra los Banu Qasi y contra Pamplona, logrando hacer muchos prisioneros. Entre ellos destacaban Mutarrif ben Musa, su secretario y los hijos de aquél. El emir ordenó ejecutar a Mutarrif y a sus hijos, mientras que el secretario fue liberado, a lo que exclamó: "No hay bien en la vida después de éstos», por lo que fue antepuesto a ellos en el ajusticiamiento. Sus cabezas fueron alzadas. SOUTO LASALA, Juan Antonio, «El emirato de Muhammad I en el Bayan al-Mugrib de Ibn Idari», Anaquel de Estudios Arabes, VI, 1995, p. 226.

Año 1038. El ejército granadino, al mando de Buluggin hermano del rey Badis ibn Habus al-Muzaffar, derrota y mata en batalla a Zuhayr, príncipe de Almería, apoderándose de las comarcas cercanas a la ciudad y haciendo prisionero al secretario de Zuhayr, Walad'Abbas, al que ordena ejecutar, «declarándole responsable de haber instigado esta discordia y en venganza por otros muchos agravios anteriores, como hablillas groseras y criminales manejos que le hizo saber al condenarlo». El siglo XI en primera persona. Las «Memorias» de Abd Allah, último rey zirí de Granada, destronado por los almorávides, traducidas, con introducción y notas por LÉVI-PROVENÇAL, Évariste y GARCÍA GÓMEZ, Emilio, Madrid, 1980, pp.104-5. Según la Crónica anónima de Sahagún, ed. UBIETO ARTETA, Antonio, Zaragoza, 1987, p. 25, Badis ordenó que le cortaran el cuello. El relato de IBN IDARI. La caída del Califato de Córdoba y los Reyes de Taifas, ed. MAÍlLO SALGADO, Felipe, Salamanca, 1992, p. 148, narra que después de su victoria sobre Zuhayr, Badis ordenó separar a los prisioneros en dos grupos, los pertenecientes a la gente de guerra, que ejecutó, y a las gentes de pluma, entre los que se incluía Walad'Abbas. De éstos sólo ordenó la muerte de aquellos que habían luchado en su contra.

También podemos mencionar el caso de Roberto el Leproso, muerto por Tughtegin de Damasco, pese a haber ofrecido diez mil dinares por su rescate. Se le reprochó este gesto, invocando la dificultad de pagar a sus tropas, pero respondió que no conocía mejor manera de meter miedo a los francos. GRAVELLE, Op. cit. (n. 5), p. 41. Finalmente, en este mismo ámbito puede recordarse la ejecución ordenada por Saladino de los prisioneros de las Órdenes Militares capturados en Hattin, a causa del violento miedo que daban a los musulmanes por su bravura. GRAVELLE, Op. cit. [n. 5], p. 39.

${ }_{18}$ Es bien conocida la extrema crueldad de Pedro I durante todo su reinado contra nobles y caballeros que en algún momento incurrieron en sus sospechas, también el episodio de la ejecución del vicealmirante Mateo Mercer en 1360, después de haber sido capturado por naves castellanas, ZURITA, Jerónimo, Anales de la Corona de Aragón, ed. CANELLAS LÓPEZ, Ángel, Zaragoza, 1967..., 7 vol. lib. IX, c. XXIX; LÓPEZ DE AYALA, Pedro «Crónica de Pedro I», Crónicas de los Reyes de Castilla, I, Biblioteca de Autores Españoles (BAE), t. LXVI. c. 13, pp. 505-6. Vid. también RAMOS LOSCERTALES, Op. cit,[n. 13], pp. 176-8, pero, evidentemente, el acto que le cubrió de oprobio ante el Príncipe Negro y los principales caballeros franceses e ingleses, fue la muerte de algunos prisioneros castellanos inmediatamente después de la batalla de Nájera en 1367.

19 Año 1500. Cerco de Faenza por César Borgia, finalmente negocia la capitulación de la ciudad y promete perdonar la vida de su señor llamado Astorga y de su hermano. Después mandó llevarlos a 
Sin llegar a esos extremos, hubo ocasiones en las que prisioneros importantes fueron muertos en el transcurso de los conflictos que enfrentaron a distintas potencias, como en la Guerra entre Francia y Aragón en 1474, cuando los franceses ejecutaban a prisioneros de cuenta del Rosellón por considerarlos traidores ${ }^{20}$, en las Guerras de Italia en venganza por la muerte o el despojo de los muertos ${ }^{21}$ ó, también, para evitar conflictos. En este sentido, podemos recordar el famoso episodio en el que Sancho de Aragón, arzobispo de Toledo, fue muerto por el arráez de Málaga para evitar discordias entre los capitanes que se disputaban tan ilustre prisionero ${ }^{22}$.

También, en ocasiones, hubo actos de violencia ciega, de crueldad extrema a cargo de mercenarios o corsarios como forma de infundir el más absoluto terror entre los enemigos y obligarlos a una guerra sin cuartel, en la que ni tan siquiera la vida de los prisioneros ilustres estaba a salvo ${ }^{23}$.

En páginas anteriores hemos considerado el destino de prisioneros importantes, nobles, infantes e incluso reyes, a los que su condición social no libró de la muerte, por tanto no resulta difícil imaginar la suerte que esperaba a la gran mayoría de los prisioneros, gentes sin recursos que constituían una engorrosa carga

Roma y pocos días después ordenó su muerte, "Crónica del Gran Capitán», Crónicas del Gran Capitán, ed. RODRÍGUEZ VILLA, Antonio, Madrid, 1908, II, c. XVIII, p. 76. También es bien conocido el famoso episodio de Senigaglia en 1502, cuando capturó mediante una famosa estratagema a un grupo de condotieros, ordenando su ejecución.

20 Año 1474. Conquista de Elna por los franceses, dejan salir a ciertas gentes del reino de Valencia y de Nápoles aunque sin armas ni caballos. Crónica Anónima de Enrique IV de Castilla (1454-1474), ed. SÁNCHEZ PARRA, M ${ }^{\mathrm{a}}$ Pilar, Madrid, 1991, 2 vol. $2^{\mathrm{a}}$ parte, c. 95, pero no al gobernador del Rosellón y otros caballeros, a los que cortaron la cabeza en Perpiñán días después, ZURITA, Op. cit. [n. 18], XIX, XI. VALERA, Diego de, «Memorial de diversas hazañas», Crónicas de los Reyes de Castilla, III, (BAE), t. LXX, pp. 3-95, c. 98

Año 1491. Guerra en Cataluña protagonizada por el conde de Pallars, que mata a Juan de Ansa, caballero muy servidor del Rey don Fernando, a quien tenía prisionero, también al capitán de la gente que custodiaba una pequeña villa que tomó y a otra la prendió fuego con la gente dentro de la iglesia, $\mathrm{Fi}$ nalmente, huyó a Nápoles, donde fue capturado y, trasladado a España, murió en Játiva. ZURITA, Op. cit. [n. 18], XX, IXC.

21 Año 1502. Combate entre españoles y franceses, favorable a los primeros y de ellos solo muere de cuenta un capitán sardo llamado Antonio de Sena, asesinado por los franceses después de preso porque llevaba vestidas las armas de un capitán francés, que pocos días antes había sido muerto por el barón de la Ficara cuando lo llevaban preso dos escuderos, ZURITA, Jerónimo, Historia del rey don Hernando el Católico: de las empresas y ligas de Italia, ed. CANELLAS LÓPEZ, Ángel, Zaragoza, 1989 y ss. 6 vol. lib. V, c. 9.

22 Año 1275. Muerte del infante don Sancho de Aragón, arzobispo de Toledo. Fue capturado por los moros y todos los que iban con él, muertos o presos. Comienzan las disensiones entre los capitanes por ver quién de ellos lo llevaba preso y el arráez de Málaga, para evitar conflictos, lo mató y cortó su cabeza. ZURITA, Op. cit. [n. 18], III, XCVIII. SÁNCHEZ DE VALLADOLID, Ferrán, «Crónica del rey don Alfonso X», Crónicas de los Reyes de Castilla, I, Biblioteca de Autores Españoles (BAE), t. LXVI. pp. 3-66 [17].

${ }_{23}$ Año 1282. Victoria en la Gatona de los aragoneses. Se ordena matar al conde de Alenzon, capitán del rey de Francia, en lugar de hacerle prisionero, pese a que sus caballeros decían que podían dar quince mil marcos de plata por su rescate. MUNTANER, Ramón, Crónica, Madrid, 1970, c. 70. ZURITA, Op. cit. [n. 18], IV, XXVII.

Año 1529. Poco después de la toma del peñón de Argel, Barbarroja manda quemar al capitán y al alcaide del peñón y a otros les corta la cabeza. LÓPEZ DE GÓMARA, Francisco, «Crónica de los Barbarrojas», en, Memorial Histórico Español (MHE), v. VI, p. 396. 
para sus captores, porque resultaban caros de mantener y podían constituir un peligro latente. Por ello, su destino siempre fue sombrío y habría que esperar varios siglos a que se impusieran condicionamientos religiosos o de simple naturaleza práctica para conservarlos.

En cualquier caso, donde la ejecución de prisioneros adquirió caracteres de enorme crueldad, de verdadera infamia, fue en las batallas navales ${ }^{24}$, en las que nadie podía dar lecciones de humanidad, ya que el destino de los perdedores era la muerte, hasta que comenzara a abrirse paso, aunque con muchas dificultades, la práctica de conservar la vida de los prisioneros para utilizarlos como galeotes. Antes de llegar a esa situación, las tripulaciones de los navíos de guerra, la chusma, estaba condenada al exterminio y existen numerosas referencias que informan acerca de esa bárbara costumbre, en la que ocupa un lugar destacado por su enorme crueldad el almirante Roger de Lauria ${ }^{25}$.

Las batallas navales que sostuvieron las flotas castellanas y catalanas contra los musulmanes fueron muy crueles, con una enorme cantidad de muertos y en las que los prisioneros eran ejecutados ${ }^{26}$. Años después, durante la guerra de los dos Pedros, el rey de Castilla ordenó el exterminio de la chusma de las naves catalanas que fueron capturadas, conservando únicamente la vida aquellos que pudieran ser de utilidad para la Marina castellana27.

En este ámbito hay un episodio que merece nuestra atención, ya que parece haber constituido una excepción en relación a esta bárbara costumbre, el elogiado gesto del almirante de Castilla Ambrosio Bocanegra de respetar la vida de los numerosos prisioneros capturados en 1372 en la batalla de la Rochela, cuya actitud contrasta con la uno de sus sucesores, Diego Hurtado de Mendoza en 1398, al or-

24 Dice el Rey Sabio que la guerra de la mar es como cosa desemparada, e de mayor peligro que la de tierra por las grandes desaventuras que pueden y venir e acaescer. PARTIDAS. II,XXIX, 1 .

25 Año 1285. Lauria carga en dos galeras una masa de prisioneros, algunos heridos y los hace ahogar. Algunas semanas más tarde, en las islas Hormigas, trescientos cincuenta heridos fueron arrojados al mar por la popa de una galera. BÉRIAC-LAINÉ, Françoise, «Les prisonniers en Europe Occidentale (XIVe et XVe siècles)», CAUCANAS, Sylvie, CAZALS, Rémy et PAYEN, Pascal (dirs.), Les prisonniers de guerre dans l'Histoire, Toulouse, 2003, pp. 107-123, [113].

Año 1299. En la guerra entre Aragón y Sicilia, Juan de Lauria fue ejecutado por rebelde y los catalanes que estaban presos padecieron grandes injurias, ZURITA, Op. cit. [n. 18], V, XXXVII.

Batalla naval entre las flota de Aragón y Sicilia, ganada por Lauria, en venganza de la muerte de su sobrino Juan manda matar a todos los prisioneros, ZURITA, Op. cit. [n. 18], V, XXXVIII.

${ }_{26}$ Sobre este particular, CALDERÓN ORTEGA, José Manuel, El Almirantazgo de Castilla. Historia de una institución conflictiva, Alcalá de Henares, 2003, pp. 24-54.

27 Año 1365. Batalla naval en la que son derrotados los aragoneses y capturadas cinco galeras, que fueron llevadas a Cartagena. En la capitana de Castilla iba el conde de Osona al servicio de Pedro I. El rey manda pasar a cuchillo a los que iban en las galeras salvo a los que sabían labrar los remos. -ZURITA, Op. cit. [n. 18], IX, LIX. PÉREZ DE AYALA, Op. cit. [n. 18], año 1365, c. 1. En ese mismo episodio, Pedro I manda ejecutar al vicealmirante Francésc d'Averso y algunos otros y, como último ultraje, ordenó arrojar al mar a los cadáveres. Un barbero barcelonés, perdonado para servir en una de las galeras cuenta haber visto los cuerpos flotando en el agua. Esta acción no fue del agrado de muchos castellanos, argumentando que se habían perdido quince mil florines que habrían tenido por el rescate de don Sent Menat que había sido ahorcado. BÉRIAC-LAINÉ. Op. cit. [n. 25], pp. 113-4. 
denar arrojar al mar a los marineros enemigos capturados ${ }^{28}$, e incluso con la práctica habitual en otras marinas europeas ${ }^{29}$.

Si esa era la suerte que aguardaba a los marineros de las flotas reales, podemos imaginar el destino de los tripulantes de barcos corsarios capturados por sus enemigos cuando intentaban realizar sus correrías. Los que no eran muertos inmediatamente $^{30}$ terminaban sus días ejecutados y expuestos a la curiosidad popular para servir de escarmiento en lugares que se harán famosos, como el puente de Londres o en la horca del almirantazgo, en el Arenal de Sevilla ${ }^{31}$.

La guerra terrestre tampoco ofrecía garantías a los prisioneros pobres, ya que su suerte estaba sujeta a una serie de circunstancias que, de no haber existido, tal vez hubieran posibilitado el respeto de su vida. Posiblemente la más trágica fuera el odio entre los distintos estamentos sociales, con episodios de gran crueldad cuando unos ú otros eran capturados por sus enemigos. Así, podemos recordar la terrible violencia con la que se emplearon los ejércitos de caballeros franceses contra los campesinos de la Jacquerie o contra los ejércitos de burgueses flamencos en batallas en las que no se reconocieron derechos a los vencidos, también muchos prisioneros castellanos fueron ejecutados por los portugueses después de Aljubarrota, ya que existía mucho odio pendiente y muchas cuentas que saldar con los invasores. Incluso en el caso de las guerras exteriores, hubo que esperar a que la suerte de las armas se mostrara esquiva con los franceses para que

${ }_{28}$ El almirante, al mando de cinco naves atacó durante el mes de mayo en aguas del Estrecho una flotilla genovesa de siete galeras, que transportaba armas y pertrechos para los portugueses. La sorpresa fue completa y la derrota total, porque sólo dos de las embarcaciones escaparon del desastre, cuatro fueron apresadas y la última encallada. Sin embargo, el almirante oscureció la brillantez de la victoria ordenando arrojar al mar a cuatrocientos de los marineros que había apresado. LÓPEZ DE AYALA, Pedro, «Crónica de Enrique III», Crónicas de los Reyes de Castilla, II, (BAE), t. LXVIII, pp. 161-271 [246]. Inmediatamente después puso rumbo a la desembocadura del Guadalquivir con las presas capturadas y los prisioneros de categoría, a los que se había respetado la vida, atracando en Sevilla ante el delirio de la población y proporcionando un espléndido botín. ORTIZ DE ZÚÑIGA, Diego, Anales de la muy noble y muy leal ciudad de Sevilla, Madrid, 1795-6, 5 vol. [II], p. 258.

29 Año 1419. La flota castellana derrota a la Hansa frente a la Rochela. El autor menciona que los alemanes arrojaban al mar a los prisioneros, mientras que los castellanos no mataban a los suyos y en adelante los alemanes dejan de matar prisioneros castellanos. GARCÍA DE SALAZAR, Lope, Las Bienandanzas e fortunas, ed. RODRÍGUEZ HERRERO, Ángel, Bilbao, 1967, 4 vol. [III], lib. XVIII.

30 Año 1424. Los genoveses matan a Martín Sánchez de Arvolancha que andaba en armada con una nao y un balliner por la costa de Portugal con todas sus compañías, que eran más de trescientos. Al cabo de ocho años, su hijo Martín mata a Luquitio, genovés, en la grada de Santa María de Sevilla porque fue el principal capitán en aquella muerte. LÓPEZ DE SALAZAR, Op. cit. [n. 29], t. IV, XXII, p. 197. La Bibliografía sobre corsarios y piratas es muy extensa, pero para el objeto de este estudio, resulta de gran utilidad la monografía de FERRER MALLOL, María Teresa, Corsarios castellanos y vascos en el Mediterráneo Medieval. Barcelona, 2000.

${ }^{31}$ Año 1161. Conquista de Carmona por los almohades gracias a la traición de uno de sus vecinos, de nombre Sarahil. El caid de la ciudad, Ibn Abi Yafar, hombre de Ibn Mardanis, se fortifica en la alcazaba pero se rinde más tarde. Hecho prisionero por los almohades, fue enviado encadenado a Sevilla hasta que llegó la orden de que fuese crucificado en el arenal. IBN SAHIB AL-SALA, Al-Mann bil-Imama, ed. HUICI MIRANDA, Ambrosio, Valencia, 1969 pp. 36-7.

Año 1507. Episodio de corsarios y se dice que en un lugar llamado Belveder en Nápoles se hacían cadenas para los prisioneros y allí fue capturado un corsario llamado Melgarejo y llevado preso a Nápoles, fue degollado por orden del virrey, ZURITA, Op. cit. [n. 21], VIII,XI. 
respetaran la vida de los prisioneros españoles y comenzaran a intercambiarlos por los de su misma nacionalidad ${ }^{32}$.

Los conflictos civiles son también ocasiones en lo que se desbordaban todos los diques de la locura y en los que afloraba lo peor de las personas, porque la venganza resulta siempre más fácil contra los más cercanos para aquellos que en algún momento se consideraron agraviados por actuaciones de sus enemigos.

Hemos hablado de distintas situaciones en las que los prisioneros fueron ejecutados, pero cuando la justificación se atribuía a razones estratégicas resultaba especialmente cruel $^{33}$, científica diríamos, ya que los captores los asesinaron a sangre fría para que no constituyeran un peligro en el futuro por su habilidad militar $^{34}$, por su conocimiento del territorio ${ }^{35}$ o para evitar que ayudasen a sus

32 Año 1473. Cerco de Perpiñán durante la Guerra de Cataluña, en su transcurso un caballero de Fernando el Católico llamado Armendáriz fue hecho prisionero en el real de los franceses junto a tres caballeros y, contra las leyes de la guerra, ejecutados. En venganza, Fernando ordenó degollar a los prisioneros franceses, cuando se enteraron los franceses del real le pidieron que no los matasen por el yerro de algunos sin el consentimiento del capitán del ejército y que en adelante guardarían las leyes, Fernando consintió. SÁNCHEZ PARRA, Op. cit. [n. 20], $2^{a}$ parte. c. 75. PALENCIA, Alonso de, Crónica de Enrique IV, traducida del latín por PAZ Y MÉLIA, Antonio, Madrid, 1904-8, 4 vol. [II], 8, c. 6.

Año 1474. Cerco de los franceses sobre Elna durante la Guerra de Cataluña. Después de conquistada, mataron a los prisioneros capturados durante la campaña, ZURITA, Op. cit. [n. 18], XIX,3.

Año 1495. Conquista de los castillos de Nápoles por el Rey de Francia, de ellos cuatro se entregan y dos resisten, finalmente se rindieron a merced y los defensores españoles, en número de ventisiete, fueron ahorcados. BERNÁLDEZ, Andrés, «Historia de los Reyes Católicos», Crónicas de los Reyes de Castilla, III, (BAE), t. 70, pp. 567-773, c. 141.

Año 1502. Noticias sobre la práctica de los rescates, al principio los franceses mataban los prisioneros españoles y éstos comienzan a hacer lo mismo, luego, cuando las cosas comenzaron a ir mal hablaron de rescatarlos, poniéndose de acuerdo. ZURITA, Op. cit. [n. 21], V,21.

33 «La frontera entre la muerte y el cautiverio se muestra como algo extremadamente sutil y azaroso. La decisión de conservar la vida de los vencidos depende de una evaluación de las ventajas y desventajas que esto puede representar con relación a los objetivos del vencedor, una decisión que debe tomarse, además, de forma inmediata, en condiciones extremas y bajo estados de fuerte excitación, por lo que no cabe esperar que se base, necesariamente, en una evaluación correcta. Esto no quiere decir, en absoluto, que las matanzas de personas indefensas sean frutos del calor del combate, ya que pueden ser perfectamente coherentes con los fines previstos por los ejecutores». TORRÓ, Josep, «De bona guerra. El ambiguo estatuto del cautivo musulmán en los países de la Corona de Aragón (Siglos XII-XIII)», FERRO, Maribel y GARCÍA FITZ, Francisco, (eds.), El Cuerpo derrotado: Cómo trataban musulmanes y cristianos a los enemigos vencidos (Península Ibérica, ss. VIII-XIII), Madrid, 2008, pp. 435-485 [442-3].

34 El propio jurista Malik negaba la posibilidad de matar prisioneros salvo alguno al que se temiera por ser enemigo conocido, por sus gestas de combate y heroísmo o similar. VIDAL CASTRO, Francisco, «Los prisioneros de guerra en manos de musulmanes: la doctrina legal islámica y la práctica en al-Andalus (s. VIII-XIII), FERRO y GARCÍA FITZ (eds.), Op. cit. [n. 33], pp. 485-507 [493].

Resulta muy esclarecedor el contenido de muchos fueros medievales, que establecían que los adalides moros fágalos el conçejo matar en qual manera lo touieren ellos por bien e commo a todos ploguieren, ya que en este caso se conjugaban circunstancias tales como el odio, las represalias, minar la moral de los enemigos, acabar con sus élites militares, etc. GARCÍA FITZ, Francisco, « $i$ »De exterminandis sarracenis»?. El trato dado al enemigo musulmán en el reino de Castilla-León durante la Plena Edad Media», FERRO y GARCÍA FITZ (eds.), [n. 33], pp. 113-167 [126].

35 Igual afán se dedicaba a la captura y muerte de los almogávares, también buenos conocedores del territorio, ya que muchos de ellos lo habían recorrido siendo esclavos. Cuando eran capturados y quedaban heridos, eran alanceados sin piedad y decapitados en el acto, siendo sus cabezas ensartadas presentadas ante los municipios. Otras veces, apresados, juzgados sumariamente y ejecutados. TORRES FONTES, Juan, «La Frontera de Granada en el siglo XV y sus repercusiones en Murcia y Orihuela: los cautivos», Instituciones y Sociedad en la Frontera murciano-granadina, Murcia, 2004, pp. 191-218 [198]. 
compañeros durante el fragor de la lucha o en cualquier otra circunstancia posterior ${ }^{36}$.

Así, hubo ocasiones en las que los vencedores en un primer momento perdonaron la vida a sus prisioneros pero posteriormente, ante el temor de que los guardianes no pudieran contribuir al esfuerzo bélico de sus compañeros en caso de un contraataque de los enemigos o de una revuelta, decidieron asesinarlos fríamente de acuerdo con una práctica que no conocía diferencias entre cristianos y musulmanes ${ }^{37}$.

Dentro de este apartado podríamos considerar otra forma de actuar que realmente produce rechazo pero que fue utilizada frecuentemente, la rendición de fortalezas bajo la amenaza de asesinar a prisioneros que, cuando resultaba un éxito, ahorraba vidas. No cabe duda de que un caso famoso fue el que tuvo como pro-

36 Es un lugar común que en las batallas campales se trataba de inculcar a los combatientes la idea de que no debían detenerse a coger botín y continuar la persecución y matanza del enemigo y, en este sentido, las Navas constituye un ejemplo muy depurado ya que, según el cronista, Alfonso VIII dio orden de no apresar a nadie, siendo muerto quien hiciese algún prisionero, por lo que no se tomaron cautivos. Esta táctica se usaría también, con excelentes resultados en 1231 frente a las murallas de Jerez. GARCÍA FITZ, Op. cit. [n. 34], pp. 124-5. Poco antes, en la batalla de Santa Ponza en 1229, los musulmanes en fuga fueron aniquilados, porque los perseguidores no querían capturarlos, así, cuando alguno de ellos se veía acorralado, se negaba a rendirse, resistiendo hasta la muerte. TORRÓ, Op. cit. [n. 33], p. 440.

Año 1452.Victoria de Fajardo el Bravo contra los moros y éstos mataron a los cautivos. GALÍNDEZ DE CARVAJAL, Lorenzo, «Crónica de Juan II», en, Crónicas de los Reyes de Castilla, II, (BAE), t. LXVIII, pp. 277-695, año 1452, c. 1.

${ }^{37}$ Las referencias son muy numerosas, pero por citar algunas, año 1138. Campaña contra Jaén y otras ciudades en la que una mesnada castellana fue sorprendida por fuerzas superiores, matando a los prisioneros para que no molestasen. Crónica del emperador Alfonso VII, ed. PÉREZ GONZÁLE, Maurilio León, 1997, 37, p. 105. VERLINDEN, Charles. «L'esclavage a la Peninsule Iberique», Anuario de Estudios Medievales (AEM), n7, 1970-1, pp. 577-592 [151]. Unos años más tarde, otra gran expedición de salmantinos fue sorprendida por el califa Texufin, exterminando a los cautivos que llevaban para que no les molestasen. PÉREZ GONZÁLEZ, Op. cit. 28, p. 104. En ambas ocasiones los cristianos fueron finalmente aniquilados.

Año 1225. Lucha entre el maestre de Calatrava y los moros y vence el primero, capturando muchos prisioneros. Los deja custodiados por una pequeña fuerza, pero vuelven los moros y matan a los guardianes, aunque previamente les dio tiempo para asesinarlos, luego los cristianos dieron tornada, matando a muchos moros. Crónica de Veinte Reyes, HERNÁNDEZ ALONSO, César, (coord.), Burgos, 1991, XIV,8.

Año 1231. Cabalgada de los cristianos en la que capturan quinientos cautivos, cuando son atacados por los moros capitaneados por lbn Hud. El infante don Alfonso ordena a Álvar Pérez de Castro matarlos. ALFONSO EL SABIO, Op. cit. [n. 7], c.1043. GARCÍA FITZ, Op. cit.[n. 34], p. 125.

Año 1415. En Azincourt, Enrique $V$ dio orden de matar a los prisioneros franceses porque el resultado estaba todavía indeciso e, incluso, se habían revuelto contra los captores. Asesinar a los prisioneros rendidos a cambio de conservar la vida iba contra el derecho de armas, aunque cuando el peligro había pasado dio orden de acabar la masacre. Finalmente hubo unos seis mil muertos frente a unos mil quinientos prisioneros. FLORI, Jean, La Caballería, Madrid, 2001, p.169. BÉRIAC-LAINÉ, Op. cit. [n. 25], p. 112.

Año 1419. Entrada de los moros de Vera en el campo de Salinas. La ciudad de Orihuela escribe a otros concejos para que cierren los pasos del río y los moros acometen a los guardas de un puesto y cautivan a uno de ellos. Tres cristianos encuentran a los cuatro moros y éstos degüellan a su cautivo, finalmente son muertos los tres moros y cautivo el otro, que fue llevado a la villa, donde se le dio tormento y luego fue ejecutado por haber matado al guarda. BELLOT, Pedro, Anales de Orihuela, ed. TORRES FONTES, Juan, Murcia, 2001, p. 277. 
tagonista al hijo del famoso Guzmán el Bueno, pero a lo largo de la Historia hubo episodios similares, que en ocasiones lograron los objetivos perseguidos y en otras no consiguieron impresionar a los asediados ${ }^{38}$.

Muchas veces, un incierto destino esperaba a los prisioneros capturados en los asedios de castillos y fortalezas cuando sus jefes habían decidido resistir, ya que el furor de los vencedores, después de los padecimientos sufridos durante el asedio, significó la muerte de los defensores, con la malvada paradoja de que en más de una ocasión quienes los indujeron a la resistencia, finalmente los abandonaron a su suerte cuando aquélla se hizo imposible ${ }^{39}$.

${ }^{38}$ Los ejemplos son muy numerosos a lo largo de todo el período histórico considerado, pero por citar algunos ejemplos, el episodio protagonizado por Alfonso I el Batallador durante el sitio de Ávila, cuando introdujo a algunos prisioneros en unos sarzos y fue a combatir la villa con ellos pensando que los parientes no se atreverían a atacarlos, pero como dice la Crónica en verdad los padres mataron a los hijos y los hijos a los padres. RODRÍGUEZ GARCÍA, José Manuel «Cabezas cortadas en Castilla y León, 1100-1350», FERRO y GARCÍA FITZ (eds.), Op. cit. [n. 33], pp. 347-397 [365-6].

Año 1248. El cronista menciona el gran pesar de Jaime I cuando Alfonso el Sabio conquista Enguera, que era de su señorío, corre el término de Játiva y captura diez y siete moros, que ejecuta ante los muros de esta última por no entregarse. ZURITA, Op. cit. [n. 18], III, XLIV.

Año 1339. Cerco de Tarifa por Alboazen, llevan los prisioneros de la flota y dicen que si no se entregan los ejecutan, los atan con cuerdas y dan vueltas alrededor de la plaza. El defensor, Benavides ordena tirar contra moros y cristianos y los moros los ejecutan. Gran Crónica de Alfonso XI, ed. CATALÁN MENÉNDEZ PIDAL, Diego, Madrid, 1971, c. 309.

Año 137?. Episodio en el que Robert Knollys entra en el castillo de Derval en ayuda de los sitiados y no respeta los tratados. Olivier Clisson que estaba entre los que asediaban le dice al duque de Anjou que no solo no libere los rehenes sino que debía ejecutarlos por no haber guardado el otro lo previsto, que era entregar el castillo en fecha cierta y hace ejecutar dos caballeros y dos escuderos ante los muros del castillo y el asediado ordena ejecutar todos los prisioneros que estaban en su poder, luego alzaron el campo. FROISSART, Jean, Crónicas, Madrid, 1988, pp. 328-9.

Año 1459. Enrique IV, inducido por Juan Pacheco, prende a Juan de Luna obligándole a ceder todas las villas que tenía en su poder, so pena de ser degollado. PÉREZ-BUSTAMANTE, Rogelio y CALDERÓN ORTEGA, José Manuel, Enrique IV de Castilla (1454-1474), Valladolid, 1998, p. 114.

Año 1477. Asedio de Monleón y se entrega por la amenaza de ser ejecutado su alcaide, que estaba preso. BERNÁLDEZ, Op. cit. [n. 32], c. 67.

Años 1503. 14 de agosto. Toman los franceses Roca Guillerma y llevan al alcaide atado para rendir la fortaleza, defendida solo tres soldados. Éstos no sólo no la entregan sino que arrojan pan y una espada para que lo degüellen mejor. Crónica Manuscrita del Gran Capitán, VIII, V, RODRÍGUEZ VILLA, Op. cit. [n. 18].

39 «En estas ocasiones se descargaban toda la ira y el odio acumulados, vengándose de los sufrimientos padecidos o de los agravios recibidos. La muerte de los defensores y habitantes de un punto fuerte era una práctica habitual que entró a formar parte de una especie de ius in bello no escrito». GARCÍA FITZ, art. cit. [n. 34], pp. 126-7. Evidentemente, el destino de muchos de estos defensores representaba uno de los aspectos más injustos de la guerra, ya que se habían limitado a obedecer órdenes y después de la captura padecieron el furor de sus enemigos. Por citar algunos ejemplos, año 913. Tras once días de combate es tomada la fortaleza de Fiñana. Los habitantes obtienen el aman de perdón entregando a los aliados de Ibn Hafsun, que fueron ejecutados. Después, puso sitio a la de Juviles, que se rinde entregando a la guarnición de Ibn Hafsun, en su mayoría cristianos, que fueron decapitados por orden de Abdalrrahman III, IBN HAYYAN. Crónica del califa Abdarrahman III an-Nasir entre los años 912 y 942 (al-Muqtabis V), traducción, notas e índices de VIGUERA, María Jesús y CORRIENTE CÓRDOBA, Federico, Zaragoza, 1981, pp. 58 y 62.

Año 930. Conquista de Badajoz. Los caídes del califa derrotan a las tropas del rebelde al-Yilliqi, capturando a más de setenta caballeros, que fueron enviados a Córdoba donde fueron decapitados por orden de califa. Al-Yilliqi pidió el amán, que se lo concedió Abdalrrahman III, enviando a continuación a aquél y a su familia a residir a Córdoba. IBN HAYYAN, Op. cit. p. 205. 
Normalmente, la muerte era el castigo de los mercenarios capturados en el transcurso de las guerras, porque a ellos no se les reconocían los derechos que poco a poco iban consiguiendo los soldados regulares ${ }^{40}$ y es bien conocido el odio que el

Año 1133, Alfonso I ordena la ejecución de los resistentes de Mequinenza por haber rechazado la oferta de rendición. Un año después, los defensores de Fraga se ofrecen a entregar la plaza a cambio de poder salir en paz, pero el rey de Aragón no acepta, jurando que ejecutaría a los combatientes. TORRÓ, Op. cit. [n. 33], p. 441.

Año 1412. La gente del Infante don Fernando de Castilla toma Montearagón y los partidarios de Antón de Luna fueron ajusticiados. GALÍNDEZ DE CARVAJAL, Op. cit. [n. 36], c. 26.

Año 1473. Conflictos entre el marqués de Cádiz y su hermano Manuel Ponce, el segundo intenta tomar el castillo de Marchena pero fracasa, él consigue huir pero sus partidarios prisioneros fueron colgadas. PALENCIA, Op.cit. [n. 32], II, 7, c. 1.

Mismo año. Toma de Alanís por la gente del duque de Medinasidonia en su guerra contra el marqués de Cádiz. Fueron capturados muchos prisioneros, de los cuales únicamente se libraron de morir ahorcados los ballesteros del maestre de Calatrava y el alcaide de la fortaleza, que fue tratado honorablemente. VALERA, Op. cit. [n. 20], c. 78. SÁNCHEZ PARRA, Op. cit. [n. 20], $2^{\mathrm{a}}$ parte. c. 61. PALENCIA, op.cit. [n. 32], II, lib. 7, C. 3.

Año 1474. Cerco de los franceses sobre Elna durante la Guerra de Cataluña. Después de conquistada, mataron a los prisioneros capturados durante la campaña, ZURITA, Op. cit. [n. 18], XIX,III.

Año 1495. Conquista de los castillos de Nápoles por el Rey de Francia, de ellos cuatro se entregaron y dos resistieron, finalmente se rindieron a merced y los defensores españoles, en número de ventisiete, fueron ahorcados. BERNÁLDEZ, Op cit. [n. 32], c. 141.

Año 1496. Guerra de Rosellón. Toma de Salsas por los franceses, se dan a partido los españoles salvando las vidas, pero una vez fuera, fueron muertos en su mayor parte. ZURITA, Op. cit. [n. 21], II,36

Pero, posiblemente, de todos estos episodios el más injusto fue el protagonizado por el mariscal Fernán Arias de Saavedra, rebelde en Utrera contra la autoridad de los Reyes Católicos. Después de cuatro meses de asedio, desde noviembre de 1477 hasta marzo del 78, las tropas reales tomaron la fortaleza, siendo ordenado un castigo ejemplar; el alcaide y el hijo del rebelde consiguieron conservar la vida, en tanto que los simples soldados murieron ahorcados, degollados o incluso descuartizados. El citado Saavedra, responsable último de estos acontecimientos obtendría el perdón real en septiembre de dicho año. Una vívida descripción del episodio en SUÁREZ FERNÁNDEZ, Luis, «La España de los Reyes Católicos», Historia de España dirigida por Menéndez Pidal, t. XVII, 2 vols, Madrid, 1969, pp. 279-80.

40 Año 937. Durante la toma de Calatayud se hacen prisioneros a los rebeldes Ibn Abi Sulayman y Yunus ben Abdalaziz de Daroca. El primero es ejecutado por orden de Abdalrrahman III, mientras que al segundo el califa le reprochó los beneficios que le había otorgado y las graves faltas que había cometido. Después ordenó que fuera alanceado hasta morir. También fueron capturados mercenarios alaveses que habían acudido en ayuda del señor de Calatayud, Mutarrif ben Mundir, a los que el califa mandó decapitar, siendo reunidas ante él las cabezas de los enemigos. Viendo el desastre, Hakam ben Mundir, hermano de Mutarrif, solicitó un amam de rendición al califa, concediéndoselo a él, a algunos de sus partidarios y a sus familias, siendo enviados a continuación a Córdoba. También se otorgó a cincuenta condes y principales de Álava, a quienes se les daría escolta hasta un lugar seguro. El resto de las fuerzas de Calatayud se habrían de rendir a discreción. Al día siguiente, se presentaron ante la tienda del califa los prisioneros, separándose de él a los que habían sido amnistiados. Los demás fueron muertos, juntándose sus cabezas con los ejecutados anteriormente y formando una pila de 330. IBN HAYYAN, Op. cit.[n. 39], pp. 297-298.

Año 1168. Una expedición de saqueo musulmana-cristiana que había partido de la localidad de Guadix, en poder de Ibn Mardanis, es destruida por el gobernador almohade de Granada Abu Abd Allah ben Abi Ibrahim en las cercanías de Ronda. Además de apoderarse del botín que habían conseguido durante la cabalgada los partidarios de Ibn Mardanis y de sus caballos y armas, los almohades consiguen tomar cincuenta y tres prisioneros cristianos, que fueron conducidos a Granada. Alli fueron decapitados por el propio gobernador y sus ayudantes. IBN SAHIB AL-SALA, Al-Mann bil-Imama, ed. HUICI MIRANDA, Ambrosio, Valencia, 1969, pp. 130-1.

Año 1509. Los venecianos conquistan la villa de Assula, defendida por ciento cincuenta españoles que se dieron a partido, pero todos ellos junto a su capitán llamado Rodrigo de Palacios, fueron muertos al salir de la fortaleza. Lo mismo hicieron en Castellfranco con una compañía de doscientos soldados y su capitán, Jaime de Híjar, también capturan al capitán Alvarado y lo llevan a Venecia. El cronista escribe que de los mil quinientos españoles que estaban a sueldo del emperador murieron casi todos y los demás fueron presos. ZURITA, Op. cit. [n. 21], VIII,44. 
famoso Bayardo profesaba a los arcabuceros ó el destino de arqueros y ballesteros apresados durante las distintas guerras, ejecutados después de ser cruelmente torturados ${ }^{41}$. Evidentemente, no corrieron mejor suerte los contingentes moros o cristianos que participaron en las contiendas civiles a ambos lados de la frontera ${ }^{42}$.

Incluso, aunque excepcionalmente, en alguna ocasión los prisioneros sirvieron de alimento a los enemigos, en el ámbito europeo cuando villas o fortalezas asediadas padecieron graves penurias y los defensores optaron por matar y devorar a algunos de estos desgraciados ${ }^{43}$. Pero quizá el peor de los destinos fue durante las Guerras de Conquista de América, sobre todo en las campañas de Cortés contra el imperio azteca, en las que los prisioneros capturados conocían el destino que les esperaba, servir de ofrenda a las divinidades de los pueblos indígenas y, después, ser devorados ${ }^{44}$.

41 Año 925. Uno de los partidarios de Umar ben Hafsun, el arquero cristiano Abu Nasr, es hecho prisionero y llevado a Córdoba. Abdalrrahman III ordenó que fuera crucificado y asaeteado por las muertes que había causado con su eficaz puntería. Una vez ejecutada la sentencia, el cuerpo, que parecía un erizo por la cantidad de saetas, permaneció varios días expuesto, hasta que se ordenó bajarlo y quemarlo. IBN HAYYAN, Op. cit. [n. 39], p. 156.

1058. Conquista de Viseo por Fernando I y al ballestero moro que mató a Alfonso V ordenó sacarle los ojos y amputarle pies y manos. ALFONSO EL SABIO, Op. cit.[n. 7], c. 805. Crónica de Veinte Reyes, [n. 37], VIII,4. Crónica Najerense, ed. ESTÉVEZ SOLA, Juan Antonio, Madrid, 2003, p. 164.

Año 1300. Batalla de Ponza en la que vence Lauria a los sicilianos, capturando a su almirante Conrado de Oria y mandando sacar los ojos y cortar las manos a los ballesteros genoveses que capturó. ZURITA, Op. cit. [n. 18], V, XLVII.

42 Año 1054. Batalla de Atapuerca, en la que fue derrotado y muerto el rey García de Navarra, siendo cautivados los moros que fueron al combate con él, «Crónica Silense», CASARIEGO, Op. cit. [n. 8], pp. 111-159 [147]. Según ALFONSO EL SABIO, Op. cit. [n. 7], c. 804 y la Crónica de Veinte Reyes, [n. 37], VIII, 3, fueron ejecutados, mientras que los cristianos recobraron la libertad. Año 1096. Batalla de Alcoraz ganada por el rey de Aragón en la que fue capturado el conde García de Cabrera de Nájera, ZURITA, Op. cit. [n. 18], I,XXIII. No se dio cuartel a los moros que llevaba García con él ni se mató a los prisioneros cristianos. CARLOS, Príncipe de Viana, Crónica de los Reyes de Navarra, ed. YANGÜAS y MIRANDA, José, Valencia, 1971. p. 81. También, durante la batalla de Montiel en 1369, la mayor parte de las bajas del ejército de Pedro I se produjeron entre el contingente de jinetes moros que le acompañaban. LÓPEZ DE AYALA, Op. cit.[n. 18], 1369, c. VI.

${ }^{43}$ Fue el caso, por ejemplo, en 876 cuando las tropas del visir Hasim asediaban a Al-Yilliqi en Cárquere y las condiciones de los asediados empeoraron tanto que finalmente tuvieron que comerse a sus propios muertos. En una de las salidas consiguieron dar muerte a uno de los diez capitanes de la guardia emiral, de nombre Faryun, cuya carne sirvió de alimento a los sitiados. MOLINA, Luis, «Vencedor y vencido: Hassim b. Abd al-Aziz frente a Ibn Marwan al-Yilliqi», FERRO y GARCÍA FITZ, Op. cit. [n. 33], pp. 507-31 [524-5]. También durante el cerco de Valencia por el Cid en 1093 hubo episodios de canibalismo. PORRINAS GONZÁLEZ, David,» ¿Masacre o clemencia: La conducta del Cid hacia sus enemigos vencidos», FERRO y GARCÍA FITZ, Op. cit. [n. 33], pp. 167-209 [197]

Año 1012. Escaramuza en las cercanías de Córdoba entre beréberes y partidarios de Hisham II. Uno de los visires de Sulayman al-Mustayn, Hubasa ibn Maksan, fue hecho prisionero y después asesinado por los cordobeses. Como en la ciudad se pasaba hambre, el cuerpo fue descuartizado y devorado. IBN IDARI, Op. cit. [n. 17], p. 102.

Año 1365. Cerco de Orihuela, durante su transcurso el rey Pedro I de Castilla ordena disparar contra el alcaide, matándolo y vista la traición, los defensores lanzaron flechas y piedras, matando a dos de los sitiadores, que fueron introducidos en el castillo para ser devorados. BELLOT, Op. cit..., p.143. FERRER MALLOL, Ma Teresa. Entre la paz y la guerra. La Corona catalano-aragonesa y Castilla en la Baja Edad Media, Barcelona, 2005, p. 446.

Año 1474. Se cuenta que en Perpiñán los asediados incluso llegaron a matar prisioneros y comerlos. PALENCIA, Op. cit. [n. 32], II, lib. 10, c. 8.

${ }_{44}$ Año 1519. Muerte de varios españoles capturados por los indios. DÍAZ DEL CASTILLO, Bernal, Historia verdadera de la conquista de la Nueva España, Madrid, 1984, 2 vol, [II], p. 1. 


\subsection{La muerte de rebeldes y traidores}

La rebeldía o la traición contra el monarca o las autoridades constituidas eran delitos que se pagaban muy caros y los hidalgos eran decapitados y los ricoshombres tratados con la misma crueldad que los hombres viles «... et mandábalos matar de cruas muertes así como a homes viles, echándolos a las bestias que los desmembrasen; o matándolos de fambre o echándolos en fondón de las aguas que los comiesen los pescados para que nuca paresciere ninguna cosa dellos». ${ }^{45}$, aunque conviene señalar que en ocasiones y por consideraciones políticas, muchos rebeldes fueron perdonados cuando aún estaban en libertad pero, evidentemente, si eran capturados mediante el empleo de la fuerza su suerte estaba echada y la muerte, que en ocasiones revestía una especial crueldad, se utilizaba como advertencia para el futuro, como en los caso del infante don Fadrique, hermano de Alfonso X, de Alfonso Fernández Coronel o del maestre Martín Fernández de Córdoba ${ }^{46}$.

Mismo año. En la Noche Triste fueron muertos y sacrificados ochocientos setenta soldados en México, setenta y dos españoles, cinco mujeres y mil doscientos tlaxcaltecas en Tustepeque. DÍAZ DEL CASTILLO, Op. cit., p. 7.

Mismo año. Los aztecas atacan a un grupo de jinetes entre los que estaba Cortés y capturan dos mozos de espuelas que fueron sacrificados. DÍAZ DEL CASTILLO, Op. cit., p. 11.

Mismo año. Durante el sitio de México, ataque de los aztecas, capturando a sesenta y dos soldados, que fueron sacrificados y sus cabezas enviadas contra los atacantes. DÍAZ DEL CASTILLO, Op. cit., p. 12.

45 PARTIDAS, II, XXVIII,2, ALFONSO ANTÓN, Isabel, «El cuerpo del delito y la violencia ejemplar. Notas sobre la justicia medieval», FERRO y GARCÍA FITZ, Op. cit. [n. 33] [403-4].

Año 939. Batalla de Simancas. Es capturado el rey moro de Zaragoza y trasladado a León, siendo ejecutado por haber traicionado a Ramiro, SAMPIRO. «Crónica», ed. CASARIEGO, Op. cit. [n. 8], pp. 79103 [97], y ZURITA, Op. cit. [n. 18], I, VIII.

${ }^{46}$ Uno de los objetivos de la guerra contra el noble rebelde era su captura, luego el encarcelamiento podía durar hasta la devolución de las plazas ocupadas durante el conflicto y solía acompañarse de la confiscación de tierras y bienes. ALVIRA CABRER, Martín, «Rebeldes y herejes vencidos en las fuentes cronísticas hispanas (siglos XI-XIII)», FERRO y GARCÍA FITZ, Op. cit. [n. 33], pp. 209-57 [214].

Año 870. Amrus ben Umar ben Amrus ben Yusuf traiciona y mata al gobernador de Huesca Musa ben Galindo y se adueña de la ciudad. Se envían tropas para reconquistar la ciudad al mando del «arif» Abdala-la; Amrus huye, siendo capturado uno de sus cómplices, Lubb ben Zakariyya ben Amrus, que fue muerto y colgado en la ciudad. SOUTO, Op. cit. [n. 17], pp. 224-225.

Año 871. Abdalgafir ben Abdal-Aziz, que estaba en Tudela, parte hacia la frontera y captura a los rebeldes Zakariyya ben Amrus, a sus hijos y a numerosos parientes. Se presenta con ellos en Zaragoza y ordena su ejecución, enviando luego las cabezas a Córdoba. SOUTO, Op. cit. [n. 17], p. 225.

Año 889. El gobernador de Sevilla Umayya ben Abd al-Gaffir ordena detener a Ibn Jattab y a la delegación que va a entrevistarse con él mientras se produce una rebelión en la ciudad hispalense aprovechando este suceso y orquestada por Ibn Jattab. El palacio del gobernador es sitiado y se pide ayuda a Ya'ad ben Abd al-Gaffir, quien derrota a los revoltosos. Umayya ordena la ejecución de lbn Jattab y de sus acompañantes. GURAIEB, J. E., «Al-Muqtabis de Ibn Hayyan», Cuadernos de Historia de Espa$\tilde{n} a,(C H E), n^{\circ}$ 29-30, 1959, pp. 155-157.

Año 919. Durante la campaña que dirige el propio Abdalrrahman III contra el hijo de Ibn Hafsun, Yafar, se toma la localidad de Belda. La población se rinde al emir si garantiza sus vidas, petición a la que accede, pero la guarnición se atrinchera y resiste a las tropas emirales. Éstas asaltan la posición, matando en la lucha a gran número de enemigos y logrando apresar a los principales jefes. Enviados atados al pabellón del emir, éste ordenó su decapitación. IBN HAYYAN, Op. cit. [n. 39], p. 121.

Resulta bien conocido el episodio de la muerte del infante don Fadrique, hermano de Alfonso X, ahogado en el castillo de Burgos en 1277, a la que siguió poco después la de Simón Ruiz de los Cameros, 
Curiosamente, resulta muy distinta la consideración que el Islam atribuye a los rebeldes, ya que no podían ser ni matados ni torturados ni encarcelados ${ }^{47}$, aunque la realidad histórica informa que los gobernantes musulmanes no se diferenciaron de los cristianos a la hora de castigar la rebeldía y la traición.

En cuanto al ámbito cristiano, Partidas establecía unas modalidades que podemos considerar ordinarias ${ }^{48}$.

a) Decapitación. Estaba considerada la muerte más digna, propia de la nobleza y, por supuesto, de la realeza, a la que se añadía en ocasiones la exposición pública de la cabeza, clavada en una pica o en una espada ${ }^{49}$.

b) Horca. Esta no era muerte propia de prisioneros nobles, aunque en alguna ocasión se aplicara a alguno de ellos para que fuera público escarmiento en la épo-

quemado vivo en Logroño. Estas ejecuciones despertaron un enorme revuelo en su época, tanto por la personalidad de los muertos como por la extrema crueldad con que fueron ejecutados. Existe un gran debate acerca de las causas que pudieron inducir a Alfonso $\mathrm{X}$ a ordenar ambas ejecuciones, barajándose algunas como traición, herejía o, incluso, homosexualidad. Sobre el estado de la cuestión, vid. ALVIRA CABRER, Op. cit. [n. 46], pp. 225-8.

Año 1353. Después de un largo asedio, finalmente es capturada la villa de Aguilar, en la que Alfonso Fernández Coronel había estado rebelado contra la autoridad de Pedro I. El cronista narra con tétrica precisión las últimas palabras pronunciadas por el prisionero, compendio de la mentalidad nobiliaria casteIlana; ante Gutier Fernández de Toledo, que también morirá más adelante, reconoce que lo único que le queda ya es morir lo más más apuestamente que yo pudiere como caballero. Poco después, ante el rey y su privado Juan Alfonso de Alburquerque, fue preguntado por las razones que le indujeron a proceder contra su monarca ¿Qué porfía tomastes tan sin pro, seyendo tan bien andante en este regno?, respondiendo con una frase que constituye una de las mejores definiciones del ser castellano Don Juan Alfonso, esta es Castilla, que face los omes e los gasta. Asaz lo entendí, pero no fue mi ventura de me desviar deste mal. LÓPEZ DE AYALA, Op. cit. [n. 18], 1353, c. 1. DÍAZ MARTíN, Op. cit. [n. 16], p. 101.

Año 1371. Prisión de Martín Fernández de Córdoba y de Mateos Fernández, asediados en Carmona por Enrique II. El rey de Castilla, pese a sus promesas de respetar la vida al primero de ellos, ordenó su muerte, ejecutada con mucha crueldad. LÓPEZ DE AYALA, Pedro, "Crónica de Enrique Il»", en, Crónicas de los Reyes de Castilla, II, B.A.E. t. LXVIII, pp. 1-74, año 1371, c. II. SUÁREZ FERNÁNDEZ, Luis, "Castilla, 13501406», en, Historia de España dirigida por Menéndez Pidal, v. XIV. $2^{a}$ ed. Madrid, 1976, pp. 147-8.

${ }^{47}$ Según al-Safi'i, jurista del siglo XI, un rebelde bagi es alguien que se niega a obedecer al gobernante justo y se rebela contra él recurriendo a la lucha armada. Para dar dicha calificación habrían de darse tres circunstancias; 1) que el rebelde tuviera una interpretación religiosa; 2) que llevase a cabo una acción de rebelión explícita y 3) que formase parte de un grupo más amplio y, por tanto, dispusiera de una base de poder. Poco después Ibn Hazm sostenía, a diferencia del anterior jurista, que los heridos y los fugitivos fueran muertos si la rebelión continuara o si los rebeldes hubieran recibido refuerzos, admitiendo también el recurso a técnicas de destrucción masiva siempre y cuando no existiera riesgo de perjudicar a las mujeres y a los niños del partido rebelde. En general para la problemática de la rebelión en el ámbito andalusí. SERRANO RUANO, Delfina, «Doctrina legal sobre la rebelión en juristas andalusíes», FERRO y GARCÍA FITZ, Op. cit. [n. 33], pp. 257-282 [257].

48 ....» la pena de la muerte principal... puede ser dada al que la mereciere, cortándole la cabeza con espada o con cuchillo e non con segur nin con foz de segar.... otrosí puedanlo quemar o enforcar o echar a las bestias bravas que lo maten pero los judgadores non deven mandar apedrear ningún ome, nin crucificarlo, nin despeñarlo de peña, nin de torre nin de puente nin de otro logar. PARTIDAS, VII, XXXI,6.

${ }^{49}$ En este sentido, aunque los ejemplos son muy numerosos, prácticamente interminables a lo largo de la Edad Media, algunos de los más importantes han sido recogidos por RODRíGUEZ GARCÍA, Op. cit. [n. 38], pp. 374-86, podemos recordar dos de ellos por su enorme significación, el primero, la cabeza de Pedro I fue expuesta públicamente de Castilla por orden de su hermanastro Enrique II y, por supuesto, la famosa ejecución de Álvaro de Luna, a quien después de ser degollado en la plaza de Valladolid el 2 de junio de 1453, se le cortó la cabeza para exponerla durante ocho días en una especie de garfio o garabato, con un bacín a los pies para recibir limosnas, que se llenó. 
ca altomedieval, sino más bien el castigo que se aplicaba a las guarniciones rebeldes contra la autoridad del monarca, con la cruel paradoja de que en más de una ocasión el cabecilla fue perdonado, como aconteció con el mariscal Fernán Arias de Saavedra, mientras que sus soldados pagaron con la horca el fracaso de la rebelión ${ }^{50}$.

c) Hoguera. Este tipo de ejecución, posiblemente la más dolorosa de todas, constituye la manifestación máxima del rigor punitivo, de aplicación para herejes ${ }^{51}$ y traidores, pero siempre con un claro carácter ejemplarizante ${ }^{52}$.

Muy recientemente, además de las anteriormente expresadas, Alvira Cabrer ha establecido una clasificación de la distinta tipología de muertes de rebeldes nobles.

d) Ahogamiento o empozamiento. Ya se ha mencionado la muerte del infante don Fadrique, hermano de Alfonso X, también podemos recordar un famoso episodio en el que el obispo Lope de Barrientos fue amenazado con esa cruel muerte a comienzos de $1444^{53}$, pero cuando existen más referencias de prisioneros muertos por este procedimiento es durante el desarrollo de las durísimas contiendas civiles que enfrentaron a los banderizos vascos en los últimos siglos medievales ${ }^{54}$.

d) Arrastramiento y mutilación. Así, el famoso episodio del cerco de Carmona, donse se refugiaron algunos de los más irreductibles partidarios de Pedro I junto a sus hijos, que culminó en 1371 con la rendición de la villa. Finalmente, Mateos Fernández y Martín López de Córdoba negociaron con el maestre de Santiago Fernán

50 ALVIRA CABRER, Op. cit. [n. 46], p. 221 y ss. Sobre el episodio del mariscal Fernán Arias de Saavedra, rebelde en Utrera contra la autoridad de los Reyes Católicos. Vid Nota 39.

51 La cruzada albigense ha dejado para la posteridad algunas muestras de este castigo inhumano. Así, después de la conquista de la fortaleza de Lavour fue encendida la mayor de las hogueras de la cruzada, en la que perecieron cuatrocientos herejes cátaros y valdenses. ALVIRA CABRER, Op. cit. [n. 46], pp. 246-7. Para Castilla contamos con el episodio de los famosos herejes de Durango, narrado por la crónica de Juan II, que informa acerca de la muerte en la hoguera de muchos de estos desgraciados en $\mathrm{Va}$ lladolid y Santo Domingo de la Calzada. GALÍNDEZ DE CARVAJAL, Op.cit. [n. 36], 1442, c. VI, p. 608. Es famoso también el episodio de Simón Ruiz de los Cameros, quemado en 1277 por el infante don Sancho por orden de Alfonso $\mathrm{X}$, al que se acusaba junto al infante don Fadrique, de haber conjurado contra el rey y, quizá, de homosexualidad o herejía. ALVIRA CABRER, Op. cit. [n. 46], p. 228.

Año 1487. Una vez desalojadas las mazmorras de la alcazaba de Málaga de los cautivos cristianos, pasaron a ocuparlas nueve herejes y tornadizos capturados en la ciudad, dos lombardos y los siete restantes de tierra de Castilla. Murieron asaeteados y sus cuerpos fueron quemados. TORRES BALBÁS, Leopoldo, «Las mazmorras de la Alhambra», Al Andalus, IX, 1944, pp. 198-218 [203].

52 Así, las muertes de Ruy, Íñigo y Diego Vela, responsables junto al conde Fernando Láinez del asesinato del conde García de Castilla o las de reconocidos traidores durante los reinados de Alfonso XI o Enrique II. ALVIRA CABRER, Op. cit. [n. 46], p. 227-8. También, dentro de este ámbito podemos mencionar la muerte del maestre de Alcántara en 1339, degollado y luego quemado o la de Martín López de Córdoba en 1371 , ya referidas.

53 El almirante de Castilla Fadrique Enríquez, cuando fue informado de las maquinaciones del citado obispo para liberar al rey Juan II de Castilla, en un arrebato de ira le amenazó con la célebre sentencia que a grado del rey de Navarra ya él sería empoçado, CARRILLO DE HUETE, Pero, Crónica del Halconero de Juan II, ed. CARRIAZO, Juan de Mata, Colección de Crónicas Españolas, VIII, Madrid, 1946.

54 Año 1360. Juan López de Salazar cerca en una casa en Güenes a Juan Marroquín junto a trece hombres y dicen que se dan a prisión con condición de que les pusiera ante el señor de Vizcaya sanos y vivos, de allí fueron llevados a la iglesia del lugar ante un clérigo llamado don Juan, quien les dijo que confesasen, siendo empozados a continuación. LÓPEZ DE SALAZAR, Op. cit. [n. 28], IV, XXIV, pp. 293-4. 
Ozores las condiciones de capitulación de la plaza y el respeto de sus vidas. Sin embargo, Enrique II incumplió sus promesas al ordenar la ejecución de ambos de una manera cruel y humillante para que sirviera de advertencia a los emperegilados, además en días distintos para prolongar la diversión del populacho sevillano, ya que el primero fue arrastrado por toda la ciudad y degollado después de cortarle pies y manos. Al segundo se le reservó un final todavía más cruel, porque padeció las mismas torturas y, posiblemente todavía con vida, fue quemado en la plaza de San Francisco ${ }^{55}$.

e) Muerte del traidor a manos del propio rey. Sin duda alguna, esta modalidad demuestra una terrible frialdad, al tratarse de ejecuciones sumarias a cargo del monarca o de alguno de sus oficiales. Fue el caso de la muerte de Diego López de Haro a manos de Sancho IV ${ }^{56}$, también la del maestre de Santiago don Fadrique por orden de su hermanastro Pedro I en el alcázar sevillano en 1358, mientras el rey se había hecho servir la comida ${ }^{57}$ o la muerte del marqués de Denia don Fernando, decidida por su hermanastro el rey Pedro IV de Aragón ${ }^{58}$. Nuevamente Pedro I asesinó a sangre fría al traidor Íñigo López de Orozco después de la batalla de Nájera ${ }^{59}$, o también numerosos ejemplos en el mundo musulmán ${ }^{60}$. Pero, evidentemente, debíamos mencionar en esta categoría el caso más famoso de la historia medieval de España, con la particularidad de que en esa ocasión fue el rebelde Enrique de Trastámara, quien de forma absolutamente premeditada asesinó a sangre fría a su hermanastro Pedro I, prisionero en su poder ${ }^{61}$.

f) La crucifixión de los enemigos y rebeldes fue también una forma de ejecución practicada por los musulmanes y estaba destinada a castigar la rebelión o la traición contra el poder constituido, como ocurrió a los rebeldes del Arrabal de Córdoba ${ }^{62}$. In-

55 LÓPEZ DE AYALA, Op. cit. [n. 46], año 1371, c. II.

56 Así narran los cronistas el episodio Diego López, ¿que vos merescí porque me corredes la mi tierra siendo mi vasallo?. E él non supo ninguna que le decir e el Rey dióle con una espada en la cabeza tres golpes en guisa que fincó muerto. ALVIRA CABRER, Op. cit. [n. 46], p. 229.

57 LÓPEZ DE AYALA, Op. cit. [n. 18], año 1358, c. III.

58 LÓPEZ DE AYALA, Op. cit. [n. 18], año 1363, c. VII.

59 LÓPEZ DE AYALA, Op. cit. [n. 18], año 1367, c. XII:

60 Año 1016. Derrota de Sulayman al-Mustayn por Ali ibn Hammud. Fue apresado junto a su hermano y conducidos a Córdoba. Allí fue asesinado por el mismo lbn Hammud, mientras que su hermano y su padre fueron decapitados. IBN IDARI, Op. cit. [n. 43], 2, p. 106. Crónica de veinte reyes, [n. 37], VI, 15.

Año 1078. Ibn Ammar, que había prometido a al-Muqtadir de Zaragoza la entrega de la villa de Segura, es apresado durante las conversaciones por uno de los esclavos de Siray al-Dawla, un hijo del rey depuesto de Denia y señor de la plaza. Después, después de pagar por él, fue entregado a al-Mutamid de Sevilla, quien «le dio la peor muerte» por la traición que cometió. El siglo XI en primera persona. Las «Memorias» de Abd Allah, último rey zirí de Granada, destronado por los almorávides, traducidas, con introducción y notas por LÉVI-PROVENÇAL, Evariste y GARCÍA GÓMEZ, Emilio, Madrid, 1980, p. 168.

61 LÓPEZ DE AYALA, Op. cit. [n. 18], año 1369, c. VIII.

62 Año 818. Rebelión del Arrabal de Córdoba. Sofocada la revuelta y habiendo cogido prisioneros a un gran número de prisioneros, Alhakam I ordenó que trescientos de ellos fueran degollados y posteriormente crucificados delante del Alcázar. Al resto se les ofreció un amam, con la condición que abandonaran Córdoba. IBN HAYYAN, Op. cit. [n. 39], 2, p. 56.

Año 766. Las tropas de Abdalrrahman I conducidas por Badr y Teman ben Alqama sitian Toledo y prenden al jefe rebelde Hisham ben Abd Rabbihi al-Fihri y a dos de sus principales colaboradores, quie- 
cluso, para acentuar aún más la humillación, en ocasiones fue realizada crucificando al prisionero entre animales considerados impuros ${ }^{63}$.

g) Otros tipos de muerte. Si en epígrafes anteriores hemos considerado algunas modalidades que repugnan a la mentalidad moderna, habría que reservar un apartado final para otras formas de muerte en las que los ejecutores sobrepasaron todos los límites de la infamia, al utilizar procedimientos espeluznantes para hacer sufrir lo más posible. Estas ejecuciones respondían a una clara motivación ejemplarizante, ya que se reservaba a notorios traidores y rebeldes que habían ofendido gravemente la dignidad del gobernante. Entre ellas, destaca especialmente el desmembramiento, aplicado en ocasiones a personas vivas ${ }^{64} \mathrm{y}$ en otras después de haber sido ejecutadas ${ }^{65}$.

nes son conducidos a Córdoba y crucificados. MACHADO MOURET, Osvaldo, «Historia de los árabes de España por Ibn Jaldun», Cuadernos de Historia de España (CHE), n 8, 1947, pp. 149-150.

Año 805. Aprovechando la represión de una conjura en la que ordenó la crucifixión de setenta y dos notables cordobeses, Alhakam I ejecuta a sus tíos Maslama y Umayyah, hijos de Abdalrrahman I. IBN HAYYAN, Op. cit. [n. 39], 2, p. 41.

Año 1153. Después de tomar Bugía, el califa almohade Abd al-Munin ordena la detención en Ceuta de Islitan, pariente de al-Mahdi, el fundador del imperio almohade. Es llevado encadenado a su presencia y ordena su ejecución y crucifixión en las puertas de la ciudad de Marrakech. IBN ABI ZAR, Rawd alQirtas, traducido y acotado por HUICI MIRANDA, Ambrosio, 2 vol. Valencia, 1964, pp. 387-388.

Año 1161. Conquista de Carmona por los almohades gracias a la traición de uno de sus vecinos, de nombre Sarahil. El caíd de la ciudad, Ibn Abi Yafar, hombre de Ibn Mardanis, se fortifica en la alcazaba pero se rinde más tarde. Hecho prisionero por los almohades, es enviado encadenado a Sevilla hasta que llegó la orden de que fuese crucificado en el arenal. IBN SAHIB AL-SALA, Op. cit. [n. 40], pp. 36-37.

En ocasiones, aparecen referencias de crucifixiones de herejes musulmanes o de prisioneros cristianos, en las que los cronistas no mencionan que hubieran sido previamente ejecutados, lo que hace pensar que la crucifixión pudiese ser previa a la muerte en la cruz. Año 913. Incumpliendo el juramento de obediencia que había realizado a Abdalrrahman III tras ser liberado de la cárcel, Muhammad al-Yayyani se rebela en África, siendo capturado y ejecutado en Córdoba mediante la crucifixión. IBN HAYYAN, Op. cit. [n, 39], p. 53. Año 916. La guarnición bereber se subleva a favor de los fatimíes contra el gobernador aglabí Ibn Qurhub, haciéndole prisionero a él y a su hijo. Enviados ante el califa Ubayd Allah, éste los interroga y después ordena que sean paseados por Qayrawan y crucificados. IBN AL-JATIB. IBN AL-JATIB: Kitab a'mal al-a'alam. Parte $3^{a}$. Historia medieval islámica del Norte de Africa y Sicilia, ed. CASTRILLO, Rafaela, Madrid, 1983, pp. 85-86.

${ }_{63}$ El gobernador musulmán de Al Andalus, Qatan fue crucificado durante el gran levantamiento de los bereberes entre un cerdo y un perro, dos animales impuros. BRONISCH, Alexander Pierre, Reconquista y Guerra Santa. La concepción de la guerra en la España cristiana desde los visigodos hasta comienzos del siglo XII. Granada, 2006, p. 131.

64 Año 934. En desacuerdo por el pacto de sumisión firmado por la reina Toda con Abdalrrahman III, Fortún Garcés, tenente del castillo de Falces, abandona a la reina y se retira a su fortaleza. El califa marchó con su ejército contra él. Temiendo la derrota, Fortún Garcés sale a su encuentro sin haber solicitado salvoconducto. Abdalrrahman III le ofreció su protección a él y a su familia si entregaba el castillo de Falces, lo cual es rechazado. Entonces ordenó su prisión y que estuviera vigilado, lo que provocó por parte del pamplonés manifestaciones de ira contra la persona de Abdalrrahman III. Éste ordena su ejecución, siendo descuartizado en el campamento con gran alegría de los soldados. IBN HAYYAN, Op. cit. [n. 39], p. 253.

Año 1108. Después de la muerte de su hijo en Uclés, Alfonso VI asedia Córdoba y por la noche hay un intento de atacar su real, captura a un moro llamado Abdalá que había matado al padre de Zaida y el rey manda hacerle piezas y quemarlo junto al resto de los prisioneros nobles. ALFONSO EL SABIO, Op. cit. [n. 7], c. 885 .

65 Año 1487. Después de la muerte del fanático que quiso matar a la Reina y atacó a su dama Beatriz de Bobadilla, le hicieron cuartos y sus restos fueron arrojados a la ciudad en un trabuco, los defensores cogieron a uno de los prisioneros que pensaban que su pérdida sería más sensible, lo mataron, abrieron sus entrañas, colocándolo en un burro y enviándolo a los reales. PALENCIA, Alonso de, Guerra de Granada, Granada, 1998, VII, p. 306. 
Todavía resulta más cruel otra forma de muerte en la que algunos desgraciados fueron literalmente cocidos, para infundir el terror más absoluto entre aquellos que osaran oponerse al poder de los gobernantes ${ }^{66}$.

Cuando los rebeldes no eran personajes de categoría los castigos eran aún más brutales, ya que perseguían un claro objetivo ejemplarizante para que sirviera de escarmiento y de advertencia para los seguidores de los nobles rebeldes contra el poder del monarca ${ }^{67}$. En ocasiones, los reyes se conformaron con la ejecución del cabecilla ${ }^{68}$, pero en otras, la larga mano de su justicia se aplicó de forma indiscriminada, independientemente del grado de protagonismo que hubieran tenido durante la revuelta y, por supuesto, de la religión que profesaran ${ }^{69}$. En este supuesto, los ejemplos son estremecedores ya que fueron ejecutados numerosos

66 Año 1066. El rey de Sevilla ordena preparar un banquete en honor de los emires. Acabado éste, fueron al baño y, una vez dentro, la puerta de la habitación fue tapiada ordenando al calderero que avivara el fuego, calentándose el baño y muriendo los emires sofocados. IBN IDARI, Op. cit. [n. 43], 2, p. 225.

Año 1115. Asedio de Ávila por Alfonso el Batallador, hace cocer a los que tenía por rehenes en calderas una gran pieza y el lugar se llama ahora de la Fervencia. Crónica de la población de Ávila, ed. HERNÁNDEZ SEGURA, Amparo, Textos Medievales, 20, Valencia, 1966, pp. 20-1.

67 Año 1333. Alfonso XI asedia una casa fuerte de Briviesca, guardada por un tal Diego Gil, desde donde le arrojaban piedras. Se acordó dejarlos ir a cambio de entregarla y, cuando se dio, el rey mandó prender a todos los defensores, convocando un consejo con los hijosdalgo que le acompañaban. Todos dijeron que habían incurrido en traición por tirar piedras contra su pendón, siendo condenados, ejecutados y confiscados sus bienes para el rey. Gran Crónica de Alfonso XI, Op. cit. [n. 38], c.159. SÁNCHEZ DE VALLADOLID, Ferrán, «Crónica de Alfonso XI». Crónicas de los Reyes de Castilla, I, Biblioteca de Autores Españoles (BAE), t. LXVI. pp. 3-66, c. 137.

Año 1334. «La resistencia de que fue objeto el monarca en Rojas por Diego Gil de Ahumada y los suyos fue considerada como traición por Alfonso XI, por lo que juzgólos luego por traydores e mandolos degollar. Tuvo tal repercusión entre los nobles esta ejecución que el cronista dice e desde entonçes los hijos dalgo pusieron condiçión en los omenajes que fizieron a los rricos omes, que si el rrey llegase al castillo o fortaleza, que qualquiera que lo tuviese por otro, que lo acogiese en el«. Pocos meses después corrieron la misma suerte Juan Martínez de Leiva y un escudero por negar la entrada al rey en el castillo de Íscar. SÁNCHEZ-ARCILLA BERNAL, José, Alfonso XI, Palencia, 1995, p. 186.

Año 1339. Revuelta del Maestre de Alcántara Gonzalo Martínez de Oviedo y cerco de Valencia de don Juan. Una a una se entregan las distintas torres hasta que solo queda la del maestre, finalmente se rinden y el maestre sale ante el rey, fue juzgado y dado por traidor, siendo condenado a ser degollado y quemado por traidor. Gran Crónica de Alfonso XI, Op. cit. [n. 38], c. 271. SÁNCHEZ-ARCILLA, Op. cit. p. 223.

68 Fue, por ejemplo, el caso de la revuelta salmantina contra Fernando II de León, que concluyó con la victoria de sus tropas y la ejecución del cabecilla Nuño Ravia en 1185. ALFONSO EL SABIO, Op. cit. [n. 7], c. 993. Crónica de veinte reyes, [n. 37], XIII, c. 8. También la del alguacil mayor de Córdoba Fernán Muñoz contra Alfonso X, recogida en ALVIRA CABRER, Op. cit. [n. 46], pp. 231-2, o la famosa revuelta de Toledo contra Juan II de Castilla en 1449, con la muerte del que osó disparar una bombarda contra el propio rey.

69 Así el famoso suceso del foso en Toledo, durante el año 797, cuando Al-Hakam ordenó al gobernador de Talavera Amrus ben Yusuf terminar con las rebeliones que estaban teniendo lugar en Toledo, recurriendo a un ardid durante el transcurso de un banquete, ordenó la decapitación de más de setecientos hombres. DE LA PUENTE, Cristina, «Cabezas cortadas: símbolos del poder y terror. Al-Andalus, s. II/VIII-IV/X», FERRO y GARCÍA FITZ, Op. cit. [n. 33], pp. 319-349 [321].

Año 1187. Toma de Gafsa por el califa Abu Yusuf. Concede el perdón a los habitantes de la ciudad y a los soldados Guzz que luchaban por los Banu Ganya, pero no al resto de las tropas enemigas, que debían esperar su juicio. Éstos fueron encarcelados en una torre de asalto y sacados por grupos, para después ser degollados. Afirma Ibn Idari que la gente de la ciudad contemplaba su ejecución y como el hierro se adueñaba de sus cuellos y de sus yugulares. IBN IDARI, Op. cit. [n. 43], 2, p.139. 
contingentes de prisioneros, a los que en ocasiones se les dio muerte de forma especialmente cruel $^{70}$.

\subsection{Las víctimas del fanatismo}

Pero sin duda alguna, la muerte de prisioneros que más repugna a la sensibilidad moderna, es la ejecutada por captores fanáticos. Cruzadas o Yihad son expresiones que con demasiada frecuencia vienen utilizándose como excusas para justificar matanzas sin control, no solo de prisioneros, sino también de poblaciones enteras, sin distinción de sexos ni edades.

Existen noticias pormenorizadas que informan de los terribles crímenes de los cruzados normandos en Barbastro en 1064, que repugnaron a los guerreros españoles participantes en dicha empresa, al aniquilar a los combatientes y esclavizar a mujeres y niños. La infamia se completó después asesinando a los prisioneros pese a las promesas recibidas, para no tener que alimentar bocas inútiles ${ }^{71}$.

Es bien conocida también la política de terror practicada por los cruzados camino de Jerusalén y cómo sus habitantes, sin distinción de sexos ni tan siquiera de religión, fueron exterminados sin piedad en una auténtica orgía de destrucción $n^{72}$.

Posteriormente, durante la larga y complicada historia de los estados francos de Tierra Santa, existen testimonios que indican que en muchas ocasiones los comandantes ordenaron a sus tropas no dar cuartel a los enemigos ${ }^{73}$.

70 Así, por ejemplo, el levantamiento de los burgueses de Sahagún en tiempo de Alfonso IX, quien ordenó la prisión de ventiocho de ellos, haciendo que les sacaran los ojos y ahorcarlos, pero el abad suplicó por su vida y el rey lo concedió a cambio de una multa de cinco mil piezas de oro. Crónica Anónima de Sahagún, ed. UBIETO ARTETA, Antonio, Textos Medievales, 75, Zaragoza, 1987, Segunda Crónica, p.135

Durante las contiendas civiles entre Alfonso X y su hijo Sancho hubo episodios de enorme crueldad, como la muerte ordenada por el infante de las gentes de Talavera que apoyaban a su padre, siendo ejecutadas más de cuatrocientas personas en 1283; en la lucha de bandos de la ciudad de Toro en 1284, o la represión masiva llevada a cabo por orden del rey en Badajoz contra el bando de los bejaranos, en la que murieron más de cuatro mil personas. ALVIRA CABRER, Op. cit. [n, 46], p. 233.

Alfonso XI asedia Valdenebro, hasta su rendición y ordena matar a todos los malhechores que estaban allí y luego en Castroponce hizo igual. Gran Crónica de Alfonso XI, Op. cit. [n. 38], c. 57.

71 Año 1064. Conquista de Barbastro por un ejército franco. Asaltan la ciudad, matando a los combatientes y apresando a las mujeres y a los niños. Ibn Idari exageradamente afirma que se hicieron cien mil prisioneros, enviando siete mil muchachas al emperador de Constantinopla, IBN IDARI, Op. cit, [ ${ }^{\circ}$. 17], p. 188 y 211. El jefe de la expedición, el normando Robert Crispín, se reservó cuatro mil. Unos seis mil prisioneros fueron asesinados fuera de la ciudad por sus captores, al ser considerados bocas inútiles a las que alimentar, p. 189, pese a haber conseguido el amman. MAÍlLO SALGADO, Felipe, «La Guerra Santa según el derecho malikí. Su preceptiva, su influencia en el derecho de las comunidades cristianas del Medievo Hispano», Studia Histórica. Historia Medieval, v. I, n² 2, 1983, p. 8.

72 Sobre la Historia de las Cruzadas puede consultarse la extensa Bibliografía que se recoge en la obra de GRAVELLE, Op. cit. [n. 5], aunque sigue constituyendo una referencia clásica la obra de RUNCIMAN, Steven, Historia de las Cruzadas, 3 vol. Madrid, 1973 y, desde la perspectiva contraria, resulta muy útil la lectura de la obra del escritor MAALOUF, Amin, Las Cruzadas vistas por los árabes, Madrid, 2003.

73 Aunque la captura de prisioneros pudiera revelarse muy lucrativa, esta circunstancia no impidió que ciertos comandantes dispusieran que sus hombres no hicieran prisioneros o, bien, asesinarlos. Bal- 
Para dicho ámbito geográfico, se ha señalado que la muerte de prisioneros no era habitual, ya que resultaba un contrasentido capturarlos para luego asesinarlos sistemáticamente ${ }^{74}$, sin embargo, existen abundantes referencias de ejecuciones de personajes importantes pese a haber ofrecido cuantiosos rescates por su libertad. En este supuesto hay que tener en cuenta el papel decisivo del fanatismo, además de tratar de aterrorizar al enemigo ${ }^{75}$.

El reinado de Saladino y la Tercera Cruzada se caracterizaron por la gran dureza de los combates y el maltrato de los prisioneros. En ambos bandos tuvieron lugar episodios de terrible crueldad que culminaron con la ejecución, ordenada por Ricardo Corazón de León, de unos tres mil cautivos musulmanes de la guarnición de Acre, librándose únicamente los prisioneros de alto rango y los más fuertes, los primeros por la posibilidad de ser rescatados $y$, los segundos, para ser utilizados en trabajos forzados.

Uno de los ejemplos más curiosos es el de Saladino, muy bien tratado en general por la Historiografía y del que se han transmitido numerosos ejemplos de magnanimidad con sus prisioneros, hasta el extremo de convertirse a principios del siglo XIII en paladín de la Caballería y un verdadero modelo de conducta para caballeros y príncipes ${ }^{76}$.

No obstante, la generosidad no constituyó la norma principal de su conducta hacia los prisioneros, ya que en más de una ocasión ordenó y presenció ejecuciones, principalmente de caballeros de las Órdenes Militares ${ }^{77}$. Curiosamente, fue responsable de más muertes que sus predecesores en la lucha contra los francos porque, a diferencia de ellos, su objetivo no era otro que el exterminio completo del Oriente Latino.

Pero, sin duda, lo que más llama la atención del observador moderno es la circunstancia de que las matanzas ordenadas por el sultán se hicieron conforme a la legalidad, ya que el derecho musulmán consentía la ejecución de prisioneros en interés de la comunidad ${ }^{78}$.

duino I ordenó a sus hombres en la batalla de Rama en 1101 «perseguir los enemigos, no envainar la espada y matarlos sin merced». Zengi destruyó un ejército franco en 1130 y ordenó a sus guerreros no dar cuartel a los francos... También en 1167 se cuenta que el comandante bizantino que acompañaba a los francos no mostraba más piedad que los otros y sus hombres no daban cuartel... GRAVELLE, Op. cit. [n. 5], p. 23.

${ }_{74}$ La cita, de Claude Cahen, en GRAVELLE, Op. cit. [n. 5], p. 32. Para el caso hispánico, ya el Cantar del Cid resumía perfectamente el concepto utilitario de los prisioneros ya los moros quedan muertos y vivos bien pocos veo. Y los que quedan con vida, a quien vender no tenemos. Si cortamos sus cabezas, nada en ello ganaremos. Dejémosles en el pueblo, pues el señorío es nuestro, posaremos en sus casas y de ellos nos serviremos. La cita en, RODRÍGUEZ GARCÍA, Op. cit. [n. 38], p. 367.

75 Así, Gervais de Bazoches, príncipe de Galilea, capturado hacia 1108 y muerto en Damasco aunque ofreció treinta mil piezas de oro por su liberación o Roberto el Leproso, señor de Saona, decapitado en agosto de 1119 por Tughtegin de Damasco, pese a haber ofrecido más de diez mil dinares. GRAVELLE, Op. cit. [n. 5], p. 32.

${ }^{76}$ GRAVELLE, Op. cit. [n. 5], p. 35.

77 GRAVELLE, Op. cit. [n. 5], p. 35-7.

78 Saladino pertenecía a la escuela chafeita y fue siempre recordado por su estricta observancia de preceptos religiosos. Son numerosas las ocasiones en que manifestó un gran respeto por los hombres de 
Los excesos de estas guerras tan crueles no escaparon a los cronistas, que intentaron justificar violencias que ya comenzaban a repugnar a los contemporáneos, con argumentos de índole militar o estratégica. Desde esta perspectiva, los cruzados asesinaron a los supervivientes de la toma de Jerusalén en la eventualidad de un asedio por el ejército fatimí. Años después, Saladino ejecutaría a los prisioneros de las Órdenes Militares por el violento temor que despertaban en los musulmanes y su bravura, a sus ojos no había duda, debían ser erradicados de la faz de la tierra por el mayor bien del Islam.

Sin embargo, en este tipo de guerras los prisioneros tenían la posibilidad de salvar la vida recurriendo a la apostasía religiosa que, evidentemente, significaba una muerte terrible en el caso de que las circunstancias de la guerra pusieran posteriormente al tornadizo en manos de sus antiguos correligionarios. Existe una larga tradición europea de conversión del infiel, aunque parece haberse dirigido más hacia la cristianización de paganos que de musulmanes ${ }^{79}$, también se han conservado numerosos testimonios que informan de conversiones durante el desarrollo de las primeras cruzadas, pero parece que fueron forzadas, como única manera de escapar a la muerte, retornando a la religión original cuando las circunstancias lo posibilitaron. No obstante, es cierto que muchos musulmanes rehusaron la fe cristiana, prefiriendo la muerte y también a la inversa ${ }^{80}$.

\footnotetext{
ley y los de religión, e imponía las reglas de la ley musulmana con rigor en lo que concernían a los prisioneros de guerra, También Nur ad din, un hanafita conocido por su piedad, se rodeaba de doctores de la ley y de sufitas, sobre todo para consultarles acerca de la suerte reservada a los prisioneros de guerra francos. GRAVELLE, Op. cit. [n. 5], p. 37.

Hubo un episodio que cuestiona el respeto por la legalidad de Saladino, surgido del problema planteado por el destino de los francos capturados cerca de Medina en febrero de 1183. El sultán era partidario de su muerte, lo que originó ciertas reticencias de su hermano al Malik al Adil, ya que se habían rendido después de recibir cuartel, el amam y legalmente debían ser respetados. Saladino decidió de otra manera y muchas cartas se cruzaron entre ambos debatiendo acerca de su suerte. Finalmente fueron ejecutados. GRAVELLE, Op. cit. [n. 5], p. 38.

79 «Esta tradición se aprecia desde Gregorio I pasando por la Chanson de Roland, en la que Carlomagno ofrece a los musulmanes vencidos la conversión o la muerte. San Bernardo en una carta de 1147 para apoyar la cruzada contra los wendos paganos, había compelido a los cristianos a convertirlos o exterminarlos y el papa Eugenio III había exhortado a los cruzados a bautizarlos. Otra razón que explicaría la ejecución de prisioneros era el rechazo del enemigo a convertirse a la religión del vencedor, aunque en ninguna de las exhortaciones o de las cartas papales, o en ninguna de las reglas de las Órdenes Militares se llamaba a la conversión de los musulmanes». GRAVELLE, Op. cit. [n. 5], p. 43.

80 Se encuentran casos de conversión durante la Tercera Cruzada, después de la rendición de la guarnición musulmana de Acre, los musulmanes que recibieron el bautismo fueron liberados, aunque muchos de ellos se unieron a Saladino, retornando al Islam. Esta circunstancia hizo que Ricardo y Felipe dispusieran entonces que nadie recibiera el bautismo. También el sultán Saladino ofreció a muchos de sus prisioneros elegir entre Islam y la muerte, sobre todo a los Templarios y Hospitalarios capturados en Hattin. GRAVELLE, Op. cit. [n. 5], p. 43.

Año 1340. Es capturada casi toda la gente de la armada del prior Ortiz Calderón y los que quisieron renegar escaparon con vida, hubo uno que no renegó, siendo ejecutado. Gran Crónica de Alfonso XI, Op. cit. [n. 38], c. 305. SÁNCHEZ DE VALLADOLID, Op. cit. [n. 61], c. 245.

Fernando el Católico dirá de Pedro de Cárdenas, cautivado en la fortaleza de Nerja en 1488, que había sido llevado a la villa de Salobreña donde murió en el dicho catyverio crudamente y por no renegar nuestra santa fe católica, por ser por descargo de su ánima. GONZÁLEZ ARÉVALO, Raúl, El cautiverio en Málaga a fines de la Edad Media, Málaga, 2005, p. 193.
} 
Evidentemente, el fanatismo no era patrimonio de las guerras entre la Cristiandad y el Islam ${ }^{81}$, ya que durante la Edad Media encontró campo abonado en distintas guerras que adquirieron la modalidad de Cruzadas y en las que comunidades cristianas fueron víctimas de otros cristianos. Así, los que profesaban distintas confesiones y tuvieron la mala fortuna de encontrarse en Jerusalén cuando los cruzados francos conquistaron la ciudad en 1099, los habitantes de Constantinopla en el infausto año de 1204 ó los habitantes del Languedoc, exterminados sin piedad y sin distinción entre católicos y cátaros por los cruzados de Simón de Montfort ${ }^{82}$.

Esta violencia ciega no era exclusiva de los cristianos, ya que los fanáticos musulmanes la practicaron en muchas ocasiones. En este sentido, las sucesivas invasiones de pueblos norteafricanos en la Península han dejado numerosos testimonios de destrucciones y de muertes no sólo de cristianos, sino también de otros musulmanes acusados de herejes, así las crueldades de los almohades sobre almorávides y muladíes ${ }^{83}$ no fueron menos crueles que contra los cristianos que osaron resistirse ${ }^{84}$, aunque en ocasiones, algunos de los protagonistas dieron lecciones de bonhomía ${ }^{85}$.

En este ambiente de fanatismo en el que las más elementales convenciones, tan lentamente aceptadas después de muchos siglos, saltaban por los aires por la crueldad de la lucha, los cristianos tampoco pueden presumir de haber respetado

81 En 1192, Celestino III afirmaba «que no era contrario a la fe católica el mandato de perseguir y exterminar a los sarracenos pues a ejemplo de lo que se lee en el libro de los Macabeos, los cristianos no pretenden adueñarse de tierras ajenas, sino de la herencia de sus padres, que fue injustamente desposeída por los enemigos de la cruz de Cristo durante algún tiempo». GARCIA FITZ, Op. cit. [n. 34], pp. 113-4.

82 Durante el transcurso de esta Cruzada se alcanzaron cotas de infamia difícilmente concebibles, fundamentalmente a cargo del ejército de Simón de Montfort, con asesinatos masivos de hombres, mujeres y niños, desde la perspectiva que nos ocupa, normalmente los prisioneros de guerra y los mercenarios capturados durante el transcurso de las operaciones fueron ejecutados sistemáticamente. ALVIRA CABRER, Op. cit. [n. 46], pp. 239 y ss.

${ }^{83}$ Año 1154. Conquista de Niebla por el caíd almohade Abu Zakariya ben Timur. Una vez tomada la ciudad por asalto, ordenó salir a sus habitantes fuera y poniéndolos en filas, hizo dar muerte a todos, incluso a los alfaquíes. El número de muertos fue de ocho mil y en la región otros cuatro mil. Después vendió a sus mujeres e hijos y les arrebató sus bienes, obrando en esto sin permiso del califa Abd al-Munin. Enterado éste de los hechos, ordenó su prisión, siendo llevado encadenado hasta Marrakech. Estuvo en prisión durante algún tiempo hasta que obtuvo el perdón, pero el cronista aclara que nunca restituyó los bienes que había robado a los habitantes de Niebla. IBN ABI ZAR, Op. cit. [n. 56], 2, pp. 389-390.

${ }^{84}$ Año 1196. Campaña de Abu Yusuf contra el reino de Toledo. Cerca el castillo de Montánchez y la guarnición se rinde al califa, concediendo el amán de protección y encargando al caíd Abu Abd Allah ben Sanadid que los lleve a un lugar seguro. Sin embargo, por el camino, fueron asaltados por un grupo de árabes que mataron a los hombres y cautivaron a las mujeres y niños. Enterado de estos hechos, el califa ordenó encarcelar a ese grupo de árabes y que el mismo caíd llevase a los cautivos a su tierra. IBN IDARI, Op. cit. [n. 17], 2, p. 194.

${ }^{85}$ Año 1196. Campaña de Abu Yusuf contra el reino de Toledo. Cerca el castillo de Montánchez y la guarnición se rinde al califa, concediendo el amán de protección y encargando al caíd Abu Abd Allah ben Sanadid que los lleve a un lugar seguro. Sin embargo, por el camino, fueron asaltados por un grupo de árabes que mataron a los hombres y cautivaron a las mujeres y niños. Enterado de estos hechos, el califa ordenó encarcelar a ese grupo de árabes y que el mismo caíd llevase a los cautivos a su tierra. IBN IDARI, Op. cit. [n. 17], 2, p. 194. 
derechos mínimos de los prisioneros, ya que la ferocidad y el desprecio de la vida del enemigo vencido fueron continuos en esos momentos de incertidumbre ${ }^{86}$.

\subsection{La política del terror}

La práctica del terror, es decir la utilización medida pero despiadada de la violencia, constituye una práctica demasiado extendida a lo largo del tiempo por distintas culturas y religiones, ya que siempre consideraron que la destrucción de determinadas ciudades o fortalezas y la muerte o cautividad de sus habitantes eran armas sumamente eficaces para favorecer el triunfo de las campañas militares y el ahorro de vidas humanas, propias o ajenas.

La impresión que producen estos actos es repulsiva, porque no se respetaron las vidas de los combatientes y, en muchas ocasiones, no escaparon ni las mujeres ni los niños. Además, resulta difícil establecer un balance acerca de si la utilización medida y precisa de la violencia a lo largo del tiempo ha sido un instrumento determinante de conquista o de triunfo, pero no cabe duda de que muchas veces el efecto perseguido fue justamente el contrario, al estimular la resistencia y el deseo de venganza de los enemigos, desencadenando una espiral de odio y violencia, cuyo fruto principal fue la muerte de demasiadas personas.

Un ejemplo claro del uso del terror fue, sin duda, la campaña depredatoria y cruel de Muza del año 713, que ocasionó la muerte o huida de muchos miles de personas, pero parece que rindió los efectos deseados, ya que la España visigoda se rindió en muy poco tiempo, aunque también resulta evidente que fueron varias las causas que pueden argumentarse para justificar la rapidez e intensidad de la conquista musulmana de la Península ${ }^{87}$. El resultado a la larga fue una violencia

${ }^{86}$ En este sentido, Inocencio III en 1210 apoyaba las intenciones del futuro Fernando III de dedicar su primera experiencia guerrera a exterminar a los enemigos del nombre cristiano de los confines de su heredad, concediendo como recompensa a quienes lo ayudaran en esta empresa los privilegios propios de la cruzada. También hay que recordar que la campaña proyectada por Alfonso VIII contra los almohades recibió privilegios propios de las Cruzadas y que varios prelados castellanos habían predicado fuera de la Península para que una parte de la Cristiandad acudiera en auxilio del rey de Castilla. GARCíA FITZ, Op. cit. [n. 34], pp. 113-4 y 121.

Sin duda alguna y como consecuencia de esta concepción de cruzada, año 1212. Campaña de las Navas, los cristianos toman Malagón y matan todos los moros que la defendían. ALFONSO EL SABIO, Op. cit. [n. 7], c. 1013. Según algún testigo presencial, antes de que se conquistase el último reducto defensivo se iniciaron negociaciones y los musulmanes propusieron la entrega de la fortaleza a cambio de que se respetasen sus vidas y se les convirtiera en cautivos, pero los atacantes no aceptaron el trato y optaron por el baño de sangre. GARCÍA FITZ, Op. cit. [n. 34], p. 120. Batalla de las Navas de Tolosa el 16 de agosto, según el cronista, Alfonso VIII dio orden de no dar cuartel, siendo muerto quien hiciese algún prisionero, por lo que no se tomaron cautivos. Después conquistaron Úbeda, matando a todos sus habitantes. IBN ABI ZAR, Op. cit. [n. 56], 2, pp. 467.

Año 1218. Conquista del castillo de Alcacer do Sal por los portugueses. Primero aniquilan una expedición de socorro almohade, acuchillando a todos sin dejar uno con vida y, después, se apoderan al asalto del castillo, matando a todos los que se encontraban en él. IBN ABI ZAR, Op. cit. [n. 56], pp. 472.

87 Año 713. Conquista de Zaragoza por los moros, crucifican señores y nobles y descuartizan a jóvenes y lactantes. LÓPEZ PEREIRA, Op. cit. [n. 7], p. 73. 
extrema por parte de unos y otros durante los primeros siglos de dominación musulmana ${ }^{88}$, expresada en campañas que muchas veces revistieron la forma de guerra de exterminio, en las que los varones fueron frecuentemente ejecutados después de su rendición y las mujeres y niños reducidos a la esclavitud ${ }^{89}$.

Pero quien supo utilizar el terror como arma de indudable valor estratégico fue Almanzor, que a lo largo de sus numerosas campañas contra los reinos cristianos ejecutó actos de una calculada crueldad, continuados por su hijo Abd al Malik ${ }^{90}$.

${ }^{88}$ Año 737. Año de la muerte de Pelayo. Carlos Martel combatió la ciudad de Aviñón y la tomó, matando todos los moros que encontró en ella. ALFONSO EL SABIO, Op. cit. [n. 7], c. 577.

Año 737. Carlos Martel captura Narbona y mata a todos los moros que apresa. ALFONSO EL SABIO, Op. cit. [n. 7], c. 578.

Hacia 750. Reinado de Alfonso I, toma muchas ciudades y mata a los sarracenos. Vid. n. 8.

89 Año 796-7. Hixem I envía una expedición comandada por Abdelquerim ben Abdelguahid contra los cristianos, en la que fueron capturados muchos prisioneros y, una buena parte de ellos, asesinados y las mujeres y los niños reducidos a esclavitud. VERLINDEN, Op. cit. [n. 37], p. 193.

Año 859. Batalla de Clavijo en la que Ordoño derrota a Muza y luego cerca Albelda, mata a todos los moros que la defienden, llevando a niños y mujeres. ALFONSO EL SABIO, Op. cit. [n. 7], c. 639. VERLINDEN, Op. cit. [n. 37], p. 193.

Año 919. Después de derrotar el ejército de Abdalrrahman III a las tropas navarras y leonesas en Valdejunquera, parte de éstas se refugian en el castillo de Muez. El emir ordena sitiar la fortaleza y, debido a la sed, la guarnición se rinde. Los combatientes fueron pasados a cuchillo en presencia de Abdalrrahman III, muriendo entre condes y principales caballeros más de quinientos hombres. De regreso hacia Córdoba, atravesando Álava, hizo innumerables cautivos y ganado, capturando también muchas cabezas de «politeístas». IBN HAYYAN, Op. cit. [n. 37], pp. 127 y 134-5.

${ }_{90}$ Año 1003. Durante la expedición contra el conde de Barcelona, Abd al-Malik envía a su liberto Wadih a capturar el castillo de Meya. El liberto asalta la fortaleza y hace a sus habitantes prisioneros. Más tarde Abd al-Malik se enfrenta con la guarnición del castillo de Montmagastre, apoderándose del castillo, capturando a los soldados supervivientes, a las mujeres y a los niños, que pasaron a convertirse en botín de guerra de los musulmanes. Algunos soldados cristianos se refugian en la alcazaba del castillo, siendo cercados por las tropas del hachib. Los cristianos se rindieron, siendo ejecutados por orden de Abd al-Malik. Finalizada la campaña, envía cartas a Córdoba afirmando en ellas que había capturado a cinco mil quinientos setenta prisioneros, destruido numerosos castillos, exterminado a sus guarniciones y cautivando a su población. IBN IDARI, Op. cit. [n. 43] pp. 14-6.

Año 1005. Durante la expedición contra León, Abd al-Malik ordena a su liberto Wadih con una columna de cinco mil caballeros que tome las fortalezas cercanas a Zamora. Éste cumple las órdenes matando a los soldados que guarnecen dichas fortalezas y cautivando a las mujeres y a los niños. Después de estas acciones, Wadih y sus tropas se encuentran con refugiados, matando a algunos de ellos y haciendo alrededor de dos mil prisioneros. IBN IDARI, Op. cit. [n. 43], p. 19.

Año 1007. Durante otra aceifa contra León, Abd al-Malik pone sitio al castillo de San Martín, derrotando a la guarnición que había salido a combatirle. Después de atacar los musulmanes a los cristianos utilizando todo tipo de máquinas e ingenios de sitio, a los nueve días éstos solicitan a Abd al-Malik un amam y poder retirarse a un lugar seguro. El hayib se niega y exige la capitulación incondicional de los cristianos. No teniendo otra salida, aceptan. Entran en la fortaleza el hermano del hayib, Abd al-Rahman y el fatá Safi, ordenando la salida de todos los pobladores. Después Abd al-Malik ordena distribuirlos en tres grupos: guerreros y hombres, mujeres y niños. "Cuando se hubo hecho eso y se le informó, cabalgó acompañado de su consejo mientras la multitud de musulmanes que le rodeaba hacía votos por él y lo aclamaba con loas y alabanzas. Detuvo su corcel en el patio de la fortaleza que miró con atención, dirigiéndose hacia el grupo formado por los hombres, que ya se había levantado en consideración a él, mientras esperaban de su clemencia que los llevaría cautivos. El los miró y aplicó la sentencia con el mismo veredicto emitido contra Sab ben Murad -Dios esté satisfecho de él-. Hizo un signo a los soldados que estaban a su alrededor; éstos entonces los pasaron a cuchillo. Enseguida ordenó la distribución de los prisioneros a los fronterizos voluntarios de la guerra santa y a los cabalgadores de los grupos irregulares, conforme a la costumbre». IBN IDARI, Op. cit. [n. 43], pp. 28-30. 
Esta práctica alcanzó una de las mayores cotas de infamia en las campañas de Basilio II contra los búlgaros a comienzos del siglo XI, aunque los cristianos peninsulares tampoco quedaron atrás en crueldades desde el momento en que la suerte de las armas comenzó a favorecerlos durante ese mismo siglo91.

Personajes de la talla de Ricardo I gozaron de una merecida fama de crueldad, no sólo por la muerte de los prisioneros de Acre, sino también porque esa fue la suerte que reservó a otros prisioneros capturados durante sus luchas contra el rey de Francia y sus hermanos ${ }^{92}$.

Pero quien ha pasado a la posteridad como paradigma de vesania es Pedro I de Castilla el Cruel, que en diversas ocasiones hizo honor a su siniestro calificativo al ordenar el asesinato de muchos de sus enemigos, reales o supuestos, a quienes deparó muertes verdaderamente horribles. También en los conflictos exteriores dio muestras de una terrible maldad, decretando la muerte de los tripulantes de los barcos aragoneses que capturó, o durante las campañas terrestres contra Pedro IV de Aragón ${ }^{93}$, alcanzando su punto culminante en 1364 cuando ordenó a sus tropas, entre las que figuraban grandes contingentes de fuerzas granadinas, llevar adelante una guerra cruel y sin prisioneros y que todo hombre apresado fuese muerto e quantos omes tomaredes cortadles las cabeças, que non finque ome de Aragón que sea tomado que no sea luego muerto94.

\subsection{Venganzas y represalias}

La represalia, a la que en el contexto considerado otorgamos su radical significado de simple venganza, constituye otra modalidad de muerte verdaderamente cruel por su componente de arbitrariedad, ejecutada muchas veces por reyes o jefes militares a quienes la Historia no ha condenado, pero que en circunstancias determinadas recurrieron a medios que no desmerecen de los utilizados por algunos de los personajes anteriormente considerados.

Estas represalias revisten distintas modalidades, en ocasiones son individuales, y afectan a una persona que incurrió en el odio del captor por alguna acción o afrenta anterior, por ejemplo, el rey Fernando I al conquistar Viseo ordenó la captura del ballestero que había acabado con la vida de Alfonso $V$ de León, al que

91 Año 1064. Conquista de Coimbra por las tropas de Fernando I. Éste hace un pacto con el gobernador de la ciudad, Rando, por el cual él y su familia pudieron refugiarse en el campo cristiano. Al día siguiente los habitantes de la ciudad, al comprobar que el gobernador no estaba en ella, pidieron un amam de protección a Fernando I, pero el rey se negó y al asaltar la población, mató a los hombres, haciendo prisioneros a las mujeres y niños. IBN IDARI, Op. cit. [n. 43], pp. 198-199.

92 En la guerra que enfrentó en Poitou a los hijos de Enrique II, Ricardo Corazón de León, modelo de la Caballería, devastó todo a su paso y ordenó en 1183 que se ejecutase a todos los prisioneros vasallos de su hermano, fuera cual fuese su rango. FLORI, Op. cit. [n. 37], p.163.

93 Año 1363. Entra el ejército del rey de Castilla en Cariñena y manda matar a todos los defensores, ZURITA, Op. cit. [n. 18], IX, XLIV. LÓPEZ DE AYALA, Op. cit [n. 18], 1363, c. 2.

94 FERRER MALLOL, Op. cit. [n. 43], p. 429. 
mandó cortar las manos ${ }^{95}$, o el famoso episodio de Ricardo Corazón de León, haciendo conducir ante su lecho al defensor que le había herido de muerte, al que perdonó la vida, pero que fue cruelmente ejecutado inmediatamente después de la muerte del monarca.

Otra modalidad muy característica de las represalias está relacionada con la muerte de personajes importantes o familiares del vencedor durante el transcurso de la batalla, en ese caso la suerte de los vencidos podía ser verdaderamente trágica $^{96}$. En otras ocasiones, se ejercieron ante el incumplimiento de cláusulas de treguas o de las condiciones de rendición de fortalezas ${ }^{97}$. Curiosamente, el uso calculado de represalias parece que resultó beneficioso para el respeto de las costumbres de la guerra ${ }^{98}$. Evidentemente, el gran problema era, sin duda, que si personas normales en ocasiones dieron rienda suelta a sus deseos de vengan$\mathrm{za}^{99}$, cuando las represalias las ejecutaron depurados ejemplos de crueldad como el corsario Barbarroja, ya en el siglo XVI, la muerte de los prisioneros fue espeluznante ${ }^{100}$.

${ }^{95}$ Año 1058. Conquista de Viseo por Fernando I y ordena sacar los ojos y cortar pies y manos al ballestero moro que mató a Alfonso V. ALFONSO EL SABIO, Op. cit. [n. 7], c. 805. Crónica de veinte reyes, [n. 37], VIII,4.

${ }_{96}$ Fue el caso de Arcila, conquistada por el rey Alfonso V de Portugal en 1471. Durante el asalto murió el conde de Marilva, por lo que todos los prisioneros fueron ejecutados salvo los mozos, mozas y niños Al parecer habían sido capturadas más de cinco mil personas. ZURITA, Op. cit. [n. 18], XVIII,XXXIX. VALERA, Op. cit. [n. 20], c. 23. SÁNCHEZ PARRA, Op. cit. [n. 20], $2^{\mathrm{a}}$ parte. c. 46. PALENCIA, Op. cit. [n. 32], II, 5, c. 7.

También podemos mencionar un acontecimiento que tuvo lugar en 1462, en una escaramuza en Villafranca, con la victoria del rey de Aragón sobre el conde de Foix, en la que murió el senescal de Bigorra. Por dicha causa fueron degollados cuatrocientos hombres de la villa que se habían refugiado en la iglesia, ZURITA, Op. cit. [n. 18], XVII, XLIV.

97 Año 1485. Castigo ejemplar contra Benamaquix por no respetar las condiciones de su rendición, ahorcando a ciento ocho moros principales. La razón es que fue conquistada por la fuerza al no entregarse dentro del plazo establecido y haber matado a algunos cristianos en las estancias. BERNÁLDEZ, Op. cit. [n. 32], $3^{\mathrm{a}}$ parte. c. 42. Cerco de Benamaquix en el que mueren más de cincuenta cristianos y el Rey se indigna cuando sabe que habían dado muerte a parte de los cautivos cristianos. Intentan pactar pero se les dice que no hay condiciones, finalmente perdona a mujeres, niños y ancianos y pasa a cuchillo a veinte de cada cien varones. PALENCIA, Op. cit. [n. 59], V, p. 178.

${ }_{98}$ Año 1473. Guerra de Cataluña, durante el cerco de Perpiñán un caballero de Fernando el Católico llamado Armendáriz es hecho prisionero en el real de los franceses junto a tres caballeros y, contra las leyes de la guerra, los franceses los mataron. En venganza, Fernando ordenó degollar a sus prisioneros y enterarse los franceses del real le dicen que por favor no los maten por el yerro de algunos sin el consentimiento del capitán del ejército y, que en adelante, guardarán las leyes de la guerra. Fernando consiente. SÁNCHEZ PARRA, Op. cit. [n. 20], $2^{a}$ parte. C. 75. Fueron degollados algunos de los principales caballeros presos y, cuando se enteraron los generales franceses, dijeron que había sido culpa de incultos leñadores y, que en adelante, guardarían mejor las leyes de la guerra. PALENCIA, Op. cit. II, 8, c. 6.

99 En este sentido, en la campaña militar que culmina en la Batalla de Las Navas, van a confluir distintas motivaciones que sirven para explicar la enorme ferocidad de las tropas cristianas, desde la derrota de Alarcos en 1195 hasta la pérdida de Salvatierra en 1211. Los cronistas escribirán que Alfonso VIII sentía la derrota de Alarcos como un deshonor y un peso insoportable que alentaba sus deseos de una venganza contra los almohades. GARCÍA FITZ, Op. cit. [n. 34], p. 121.

100 Hacia 1520. Aradun Barbarroja, cuando conoce la noticia de la muerte de su hermano Omiche, hace ejecutar a parte de los españoles que estaban cautivos en Argel. LÓPEZ DE GÓMARA, Op. cit. [n. 23], p. 379. 
Las represalias que hemos venido considerando fueron ejecutadas por reyes y jefes militares durante el transcurso de grandes campañas, pero también estos actos execrables respondieron a consideraciones menores, fruto de una iniciativa particular sin el conocimiento de sus superiores, a cargo de oficiales poco importantes 0 , incluso, de simples soldados que decidieron vengarse de similares acciones de sus enemigos ${ }^{101}$, en muchas ocasiones durante el transcurso de las tediosas y peligrosas labores de asedio de castillos y fortalezas, tan pródigas en escaramuzas que muchas veces significaron una auténtica sangría de hombres ${ }^{102}$.

Cualquier incidente brindaba motivos suficientes para ejercer represalias sobre los vencidos, constituyendo un motivo de justificación plenamente reconocido los insultos o injurias de los asediados, sobre todo si iban dirigidos contra la dignidad real, como en el famoso episodio del espingardero de Toledo y Juan II de Castilla ${ }^{103}$.

Otra modalidad de represalia o venganza que reviste una especial crueldad es la que se practica en los conflictos civiles o guerras de bandos, en las que tan pródiga fue la Historia de España, ya que es bien sabido que durante su desarrollo la

Año 1523. Fracasado asedio de Argel por parte de la flota de Hugo de Cardona, al sorprenderle una terrible tempestad que hace naufragar muchos barcos cuyos tripulantes cayeron cautivos en poder de los moros. Barbarroja ordenó matarlos en venganza de la muerte de sus hermanos, al saber que muchos de ellos eran de la guarnición de Orán. LÓPEZ DE GÓMARA, Op. cit. [n. 23], p. 381.

Hacia 1525. Barbarroja ataca el litoral de la región de Roma y pelea contra una nao genovesa que al final captura, en el transcurso de la lucha le raparon la toca de la cabeza de un tiro y, luego, cuando vuelve en sí ordenó degollar al capitán, artilleros y oficiales de la nao y a los prisioneros los repartió entre los suyos. LÓPEZ DE GÓMARA, Op. cit. [n. 23], p. 387.

101 Año 1483. Batalla en la que Luis Portocarrero y otros desbaratan a los moros haciendo muchos prisioneros. BERNÁLDEZ, Op. cit. [n. 32], 3a parte. c. 24. Esta batalla fue contra los de Zahara, capturando cien prisioneros y muchos más perdieron la vida porque en la huida y con la ira de los vencedores fueron muertos hasta los que pedían la vida salva, en venganza de la muerte de algunos caballeros de Utrera degollados por los moros. PALENCIA, Op. cit. [n. 59], III, pp. 95-6.

Año 1502. Encuentro entre españoles y franceses, que vencen los primeros y de ellos solo muere de cuenta un capitán sardo llamado Antonio de Sena, capitán de infantería, que fue asesinado después de preso porque llevaba vestidas las armas de un capitán francés que pocos días antes había sido muerto por el barón de la Ficara, ZURITA, Op. cit. [n. 21], V,9,

102 Año 1301. Cerco de Mula por las fuerzas catalanas mandadas por Bernat de Sarriá, los asediadores capturan dos espías castellanos a los que interrogan y luego ejecutan, los asediados en represalia ahorcan a dos catalanes que tenían prisioneros, que ya estaban medio muertos cuando los colgaron porque habían sido usados como escudos humanos. FERRER MALLOL, Op. cit [n. 43], p. 83.

Año 1510. Para vengar la derrota de sus tropas en Alcalá de Benarrax, sale el capitán Martín de Argote desde Orán con cien hombres y alcanza a los turcos y se rinden a partido de sus vidas, hubo discusión entre un turco y un español y éstos matan o apresan a seiscientos turcos. LÓPEZ DE GÓMARA, Op. cit. [n. 23], p. 375 .

103 Juan II de Castilla ordenó ejecutar al espingardero de Toledo que le hizo objeto de chanzas con la expresiva frase de toma allá esa naranja que te embían desde la Granja al tiempo que disparaba su arma, cuando asediaba la ciudad junto a Álvaro de Luna en 1449, GALÍNDEZ DE CARVAJAL, Op. cit. [n. 36], p. 664, pero en ese caso había que sumar el enorme simbolismo que representaba el insulto a la dignidad real.

Año 1502. Episodio de Visela en el que son prendidos los setenta defensores de una torre y los arrojaron torre abajo, donde esperaba Pedro Paz con una pica para ensartarlos. La razón que se dio para justificar esta salvajada fue el haber dedicado palabras deshonestas a los españoles y no haberse rendido a cambio de la vida. Crónicas del Gran Capitán. [n. 38], V, C. XVII. 
violencia se ejerce muchas veces como una especie de justicia privada, en respuesta a agravios anteriores, lo que genera una espiral perversa cuyo solución resulta muy complicada en tanto no se imponga un poder político fuerte y decidido a encauzar la venganza mediante el ejercicio de la justicia pública.

Lógicamente, vamos a centrar nuestra atención en la venganza que se ejecuta sobre los prisioneros, rendidos muchas veces bajo promesa de respeto de su vida y que, sin embargo, fueron ejecutados sin piedad, justificando su muerte en razones cuyo origen estaba ya envuelto en la nebulosa del tiempo. Las Crónicas aportan numerosos ejemplos de estas venganzas, pero posiblemente la obra que aporta noticias más expresivas sea Las Bienandanzas e Fortunas, terrible sucesión de muertes y venganzas en las que se vieron envueltos la mayor parte de los linajes vascos durante su compleja historia medieval ${ }^{104}$, aunque otras regiones de la Corona de Castilla no se libraron de la lacra de las guerras nobiliarias, como Andalucía con las durísimas luchas protagonizadas por el duque de Medinasidonia y el marqués de Cádiz durante los convulsos años del reinado de Enrique IV, cuando ambos nobles aprovecharon para dirimir las diferencias que venían enfrentándolos desde años atrás ${ }^{105}$.

\section{LA AFRENTA FINAL: LA EXPOSICIÓN DE LOS MUERTOS}

Una vez ejecutados los prisioneros llegaba el momento de la exposición de sus cadáveres, o de alguno de sus miembros, en lugares públicos como si se tratara de trofeos de animales, lo que constituía la humillación final, ya que ni tan siquiera se respetaba el derecho sagrado de los muertos, aceptado por las distintas religiones, a ser enterrados dignamente ${ }^{106}$. Normalmente eran los restos de rebeldes o trai-

104 Hacia 1320. Victoria muy completa de Lope García de Salazar contra las gentes de Fernán Sánchez de Velasco en Villatomín, salva la vida Fernán Pérez de Ayala porque no lo matan, tampoco hubo muchos muertos porque Lope García ordenó a sus gentes que solo mataran a los de las calzas bermejas que eran hijosdalgo y los otros solo eran hombres comunes.

Hacia 1300. Lope García derrota a las gentes de Sancha de Velasco en Zaniego y captura más de ciento veinte prisioneros con su jefe Fernán López, que había mandado matar a un sobrino suyo, le cortó la cabeza al citado López, golpeándose con ella los pechos y llama a su sobrino diciendo que mal trueque tomo yo en esta cabeza por la tuya quel cortó malamente. GARCÍA DE SALAZAR, Op. cit. [n. 28], t. IV, XXIII.

Año 1468. Escaramuza en Durango entre los de Zaldívar y Durango, siendo capturado Ochoa de Salazar, hijo de Lope García y, pese a estar asegurado por Juan de Avendaño, fue muerto en la puerta de la villa. GARCÍA DE SALAZAR, Op. cit. [n. 28], t. IV, XXII.

105 Año 1473. Combate cerca de Alcalá de Guadaira entre gentes del marqués de Cádiz y del duque de Medinasidonia, muere peleando Pedro de Guzmán y es hecho prisionero su hermano Alonso de Guzmán, quien después de desarmado fue reconocido por sus enemigos que lo degollaron, PALENCIA, Op. cit. [n. 32], XVIII, LI. También fue capturado otro hijo bastardo del duque que vestía armadura por primera vez, siendo llevado a Marchena para el canje y también quedaron prisioneros otros cincuenta. PALENCIA, Op. cit. [n. 32], 7, c. 8.

106 Año 1308. Rebelión del jeque Yusuf ben Muhammad ben Abi lyad contra el nuevo emir Abu Tabit en Marrakech. Vencido el rebelde por las tropas mariníes, huyó a las montañas de Haskura, pero el jeque Jaluf ben Hanua, que le había hospedado, le traiciona. Cargado de cadenas, fue enviado después a Abu Tabit, que ordenó su ejecución a palos, enviando la cabeza a Fez. También fueron decapitados seis- 
dores y también de capitanes enemigos, cuya contemplación habría de servir como factor esencial de desmoralización del enemigo y para animar a las fuerzas propias, siendo sin duda el más famoso el caso de Munio Alfonso ${ }^{107}$. La intimidación por este medio se justificaba para evitar nuevas revueltas en el futuro y, lógicamente, más ejecuciones ${ }^{108}$.

Evidentemente, esta costumbre requería una larga tradición en el tratamiento taxidermístico de los restos del muerto, para que pudieran conservarse hasta su llegada al lugar final de destino y su exposición durante mucho tiempo en las puertas de las ciudades ${ }^{109} \mathrm{y}$, sabemos, que los cristianos encomendaban estas prácticas a médicos judíos y musulmanes ${ }^{110}$.

Así, los viajeros que llegaban a las grandes ciudades veían como macabros adornos de puertas y murallas las cabezas cortadas de enemigos cristianos y

cientos partidarios del rebelde y sus cabezas distribuidas por diversos lugares. El emir recibe en el territorio de Tamasna a legados de los árabes Jult, Asim, Banu Djabir y otros sometidos, pero no dejó que se marchen pidiéndoles le acompañaran hasta Casablanca. Allí aherrojó a sesenta de ellos y los metió en la cárcel, mientras que decapitó a treinta. En Rabat ejecutó a otros treinta, crucificando sus cuerpos en los muros IBN ABI ZAR, Op. cit.[n. 56]. pp. 712-714.

107 RODRÍGUEZ GARCÍA, Op. cit. [n. 38], pp. 364-5. En 1143, después de su resonante victoria sobre los reyes de Sevilla y Córdoba, Munio Alfonso, mandó colgar las cabezas de los reyes y de los demás jefes militares y caudillos en la parte más alta de la ciudadela de Toledo, para que cristianos, moabitas y agarenos tuviesen un testimonio manifiesto de la ayuda de Dios. Paradójicamente, el destino que dio a sus enemigos fue el que sufrieron sus restos poco después, expuestos en los muros de Calatrava la Vieja durante varios años, ó el cadáver del almirante Alfonso Tenorio en 1340, presentado al sultán Abul Hassán y devuelto tiempo después a ruegos de sus familiares. Igual suerte corrieron los restos de Alfonso López de Córdoba, en 1424 y de García de Toledo, hijo del $2^{\circ}$ duque de Alba, muerto en los Gelves en 1510.

108 PUENTE, Op. cit. [n. 63], p. 333.

109 «El destino de la mayoría de las cabezas que eran enviadas a Córdoba era su exhibición en la puerta de la Azuda, un lugar que por la descripción de las crónicas debía ser terrorífico". PUENTE, Op. cit. [n. 63], p. 333.

Por citar algunos ejemplos, año 980. El general Galib muere luchando contra Almanzor, siendo despellejado y su piel, rellena de algodón, fue crucificada a la puerta del alcázar de Córdoba. La cabeza, clavada en una cruz, permaneció expuesta en la puerta de al Zahira durante ventinueve años. CAÑADA JUSTE, Alberto, «Las relaciones entre Córdoba y Pamplona en la época de Almanzor (977-1002)», Príncipe de Viana, n 196, 1992, pp. 371-390 [377].

Año 1009. Ibn Dura, hayib de Muhammad II apresa a Sanchuelo y al conde García Gómez en las cercanías de Córdoba. Mientras era amarrado por los soldados, Sanchuelo sacó un cuchillo pero sus guardianes acabaron con él y con el conde. Fue decapitado y enviado su cuerpo a Córdoba. Allí le sacaron las entrañas y las rellenaron de hierbas aromáticas, siendo finalmente crucificado a las afueras de la ciudad junto con la cabeza del conde. IBN IDARI, Op. cit. [n. 43], 3, p.73.

Año 1319. Junio. Muerte de los infantes Pedro y Juan en la Vega de Granada. Los cronistas musulmanes refieren que el cadáver de don Pedro fue forrado de algodón y colgado en la puerta de Granada durante muchos años. ARIÉ, Rachel, L'Espagne musulmane au temps des nasrides, París 1973, p. 97, Nota 3.

Ese mismo destino experimentaron algunos de los prisioneros españoles capturados por los aztecas en las campañas de Cortés en 1519, que habían sido muertos, desollados y adobados sus cueros. DíAZ DEL CASTILLO, Op. cit. [n. 44], II, p. 10.

110 Año 1143. «La emperatriz, movida por una gran compasión mandó bajar las cabezas de los reyes y ordenó a los médicos judíos y musulmanes ungirlas con mirra y áloe, envolverlas en los mejores paños y ponerlas en cofres repujados de oro y plata. Después las envió con todos los honores a Córdoba a las reinas esposas de estos reyes». PÉREZ GONZÁLEZ, Op. cit. [n. 37], 79, p. 119. 
musulmanes ${ }^{111}$, que en algunos casos se colocaban de forma alegórica para recordar sus nombres ${ }^{112}$, también a crucificados, costumbre muy del gusto musulmán y que normalmente era el destino que esperaba a traidores, rebeldes y cobardes ${ }^{113}$. Pero quizá el episodio más macabro fue el que ordenó Abd al Rahmán III, que después de derrotar y matar a Sulaiman Ibn Hafsun y crucificar su cuerpo ${ }^{114}$, conquistó Bobastro ordenando desenterrar el cadáver de Ibn Hafsún, muerto muchos años antes y crucificarlo en unión de sus hijos y algunos de sus principales partidarios ${ }^{115}$. Este acontecimiento, que tanto repugnó los sentimientos religiosos musulmanes, hubo que justificarlo con el argumento de que eran apóstatas y habían muerto como cristianos ${ }^{116}$.

111 Año 912. El gobernador de Calatrava de Abdalrrahman III, Ubaydallah ben Fihr, hace prisionero al rebelde Muhammad ben Ardabullis, ordenando a continuación su ejecución y enviando la cabeza a Córdoba, donde fue expuesta en la picota. IBN HAYYAN, Op. cit. [n. 39], 2, p. 51.

Año 1015. Córdoba. Los eunucos capturan a Mahomad Almahadí, se lo presentan al rey Hixem, que manda cortarle la cabeza, arrojar su cuerpo a la calle y guarda la cabeza. Crónica de veinte reyes, [n. 37], VI,9.

112 Año 917. Ordoño II vence a los moros en Gormaz y lleva a León muchos cautivos. ALFONSO EL SABIO, Op. cit., c. 672 . Después ordenó colgar la cabeza del general de los moros sobre la muralla de la ciudad junto a la de un jabalí por el significado de su nombre que era yabali o montaraz. ESTÉVEZ SOLA, Op. cit. [n. 41], p. 130.

${ }_{113}$ Año 925 . Uno de los partidarios de Umar ben Hafsun, el arquero cristiano Abu Nasr, es capturado y llevado a Córdoba. Abdalrrahman III ordenó su crucifixión, siendo asaeteado por las muertes que había causado con su eficaz puntería. Una vez ejecutada la sentencia, el cuerpo, que parecía un erizo por la cantidad de saetas, permaneció varios días expuesto, hasta que fue bajado y quemado. IBN HAYYAN, Op. cit. [n. 39], 2, p. 156.

114 Año 926. Sulayman ben Umar ben Hafsun es muerto por soldados del emir cuando, luchando contra ellos, cayó del caballo. Los soldados le cortan la cabeza, siendo enviada junto con el cuerpo a Córdoba. El emir ordenó que los restos de Sulayman fueran expuestos en una cruz junto a la puerta de la Azuda. IBN HAYYAN, Op. cit. [n. 39], 2, p. 158.

115 Año 928. Rendición de Bobastro por Hafs ben Umar ben Hafsun. Tras pedir el amam a Abdalrrahman III, le permitió irse de la ciudadela con su familia, siendo trasladados a Córdoba. Después de esta victoria, Abdalrrahman III envía a su jefe de policia, Durri ben Abdarrahmman, contra el rebelde de Algeciras, Ibn az-Zayyat. Durri apresa en una incursión a Habil y a siete cristianos, todos ellos antiguos partidarios de Ibn Hafsun. Fueron enviados a Córdoba y crucificados, al lado del cuerpo de lbn Hafsun. IBN HAYYAN, Op. cit. [n. 39], 2, pp. 164-65.

116 FERRO, Maribel, «El castigo de los herejes y su relación con las formas del poder político y religioso en al-Andalus (siglos II/VIII-VII/XIII), en, FERRO y GARCÍA FITZ, Op. cit. [n. 33] pp. 283-319 [289]. 